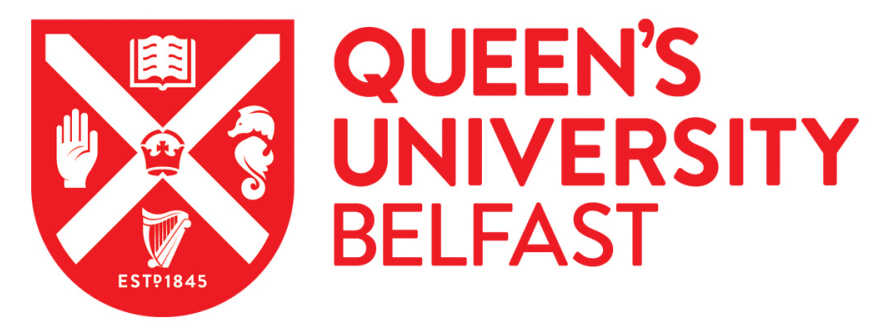

\title{
Resilience and Burnout in Child protection social work: Individual and organisational themes from a systematic literature review
}

McFadden, P., Campbell, A., \& Taylor, B. (2015). Resilience and Burnout in Child protection social work: Individual and organisational themes from a systematic literature review. British Journal of Social Work, 45(5), 1546-1563. https://doi.org/10.1093/bjsw/bct210

Published in:

British Journal of Social Work

Document Version:

Early version, also known as pre-print

Queen's University Belfast - Research Portal:

Link to publication record in Queen's University Belfast Research Portal

Publisher rights

(c) The Author 2014. Published by Oxford University Press on behalf of The British Association of Social Workers. All rights reserved.

\section{General rights}

Copyright for the publications made accessible via the Queen's University Belfast Research Portal is retained by the author(s) and / or other copyright owners and it is a condition of accessing these publications that users recognise and abide by the legal requirements associated with these rights.

Take down policy

The Research Portal is Queen's institutional repository that provides access to Queen's research output. Every effort has been made to ensure that content in the Research Portal does not infringe any person's rights, or applicable UK laws. If you discover content in the Research Portal that you believe breaches copyright or violates any law, please contact openaccess@qub.ac.uk. 


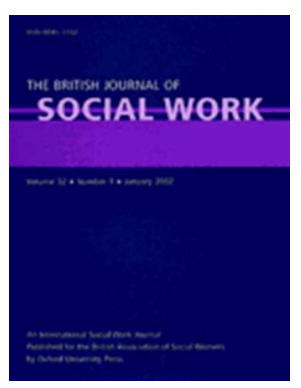

Draft Manuscript for Review. Please complete your review online at http://mc.manuscriptcentral.com/oup/bjsw

\section{Resilience and Burnout in Child Protection Social Work: Individual and Organizational Themes from a Systematic Literature Review}

\begin{tabular}{|r|l|}
\hline Journal: & The British Journal of Social Work \\
\hline Manuscript ID: & BJSW-11-287.R2 \\
\hline Manuscript Type: & Original Article \\
\hline Keywords: & $\begin{array}{l}\text { Child protection, systematic literature review, Resilience, burnout, } \\
\text { retention and turnover }\end{array}$ \\
\hline Subject Categories: & Families, Children and Young People \\
\hline \multicolumn{2}{|r}{} \\
\hline
\end{tabular}

\section{SCHOLARONE}

Manuscripts 


\title{
Resilience and Burnout in Child Protection Social Work:
}

\section{Individual and Organizational Themes from a Systematic Literature Review}

\begin{abstract}
Child protection social work is acknowledged as a very stressful occupation with high turnover and poor retention of staff being a major concern. This paper highlights themes that emerged from findings of 65 articles that were included as part of a systematic literature review. The review focused on the evaluation of research findings, which considered individual and organizational factors associated with resilience or burnout in child protection social work staff. The results identified a range of individual and organizational themes for staff in child protection social work. Nine themes were identified in total. These are categorised under 'Individual' and 'Organizational' themes. Themes categorised as individual included, personal history of maltreatment, training and preparation for child welfare, coping, secondary traumatic stress, compassion fatigue and compassion satisfaction. Those classified as organisational included workload, social support and supervision, organizational culture and climate, organizational and professional commitment and job satisfaction or dissatisfaction. The range of factors are discussed with recommendations and areas for future research are highlighted.
\end{abstract}

Key Words Burnout, child protection social work, resilience, retention and turnover, systematic literature review 


\section{Introduction}

Child protection social work is an occupation that can result in high levels of stress and burnout (Anderson, 2000). There are concerns about the level of inexperience in the child protection workforce due to high levels of staff turnover (Healy et al., 2009), and it is acknowledged that a competent and committed workforce is essential for the effective service delivery of statutory services to vulnerable children and families. Despite the evidence of the difficulties associated with this job, there is also evidence to suggest that workers can find their role rewarding and experience job satisfaction, feeling they make a valuable contribution to peoples' lives (Ellett, 2009, Nordick, 2002). Resilience is therefore apparent in some workers but not all. Factors associated with these individual differences are multifaceted and are recorded and discussed in this article.

The current paper gathers together research findings from 65 studies which together have formed a framework to provide insight into the range of individual and organizational factors associated with resilience and burnout in child protection social work. The framework is based on a career timeline perspective which begins at the point of motivation to become a social worker and then the range of factors that impact. along the career journey of the social worker form motivation, to selection to the degree to training and post qualifying training, to the organizational contest such as the impact of workload and manager and team experience., The collation of the study results have been presented in a table Systematic Review Table.doc and has been the basis of a literature review which was the foundation of empirical research sited elsewhere. 


\section{Theory and Definitions}

Job burnout was developed as an important concept during the 1970s, and it captured something extremely critical about people's experiences in the workplace. Burnout is defined as the experience of physical, emotional and mental exhaustion that can arise from long-term involvement in occupational situations that are emotionally demanding. A widely accepted definition of burnout is proposed by Maslach et al (1996:4) which encompasses the concepts of emotional exhaustion, depersonalisation and reduced personal accomplishment. A plethora of research has been devoted to the understanding of factors contributing to burnout and the consequences for individuals and their health and well-being. Research indicates that stress and burnout are significant factors in the development of both physical and psychological illness (McGrath et al., 1989).

There are many definitions of resilience that broadly reflect the conditions of adversity and adaptation. Resilience approaches focus on those who manage or overcome adversity and tend to avoid negative impacts or identify learning and benefits as a result of these experiences. According to resilience theorists, resilience, rather than distress and an inability to cope is the norm (Bonanno, 2004) and adversarial growth is also common (Arnold et al., 2005). Resilience literature has evolved from concepts related to personality factors such as adaptability and hardiness (Bonanno, 2004) and developed to include process based insights into resilience (Hart et al., 2007). This development places the individual in context and creates the ability to examine options for building resilience into organizational contexts. It is noted that this is an emerging area of research and concepts of 
resilience and adversarial growth are challenged in relation to rigour of the research and validity (Luthar et al, 2000) the link, however, offers an alternative framework worthy of consideration. While deficit models tend to focus narrowly on contributors to burnout, Bell (2003) argues that a strengths perspective can inform broader personal and organisational strategies and resources that support resilience.

This link also highlights the need and potential for systems and processes for developing strategies to build organizational resilience.

\section{Burnout and Resilience in Child Protection work}

There is evidence that child protection workers are at risk for experiencing burnout (Conrad and Kellar-Guenther, 2006; Regehr et al., 2004). Although burnout can occur in any occupational group, child protection workers are particularly vulnerable to burnout due to their poor working conditions excessive paperwork, long working hours, little opportunity for advancement, and ineffective bureaucratic structures (Anderson, 2000).

Russ et al., (2009) states that there are at least four conditions of adversity that research has identified as common experiences in child protection work. These are work stress (Dollard et al., 2001; Lonne, 2003), burnout (Maslach and Leiter, 1997), trauma (Horwitz, 2006), and vicarious traumatisation (Conrad and Kellar-Guenther, 2006). Research has highlighted the potential for these experiences to have significant adverse impacts for child protection workers and suggested that these adversities contribute to declining staff well-being (Conrad and Kellar-Guenther, 2006). This 
ultimately impacts on organisations by lowering the willingness and ability of individuals to function optimally.

Despite the predominantly negative focus on burnout, researchers have increasingly identified a proportion of child protection workers who continue to function effectively and report high job satisfaction (Conrad and Kellar-Guenther, 2006; Ellett, 2009, Nordick, 2002). Furthermore, a closer examination of the research suggests that even where negative indicators are evident, 50-70\% of study participants remain without symptoms or dysfunction (Conrad and Kellar-Guenther, 2006).

\section{Methodology}

A total of 10 bibliographic databases were selected (Psych Info, Medline, ASSIA, Social Services Abstracts, SSCI, CINAHL, Cochrane Library, Index to Thesis, Social Care Online, ZETOC) as well as the search engine Google Scholar. The selection was influenced by the Social Care Institute Guidance (Coren and Fisher, 2006) and previous random searches across available electronic databases. Other issues that were considered included accessibility, relevance to the subject and inclusion of grey literature as well as peer reviewed research. All of these databases included abstracts for the articles found which enabled the first stage of the process of selection and deselection for relevance to begin. In order to manage the quality of the current study, independent inter-rater selection and de-selection processes took place before $1^{\text {st }}$ and $2^{\text {nd }}$ raters met to discuss and agree studies to be included.

\section{Inclusion and Exclusion Criteria}


To be included papers had to focus on social workers in child protection or child welfare work. Papers on resilience amongst other professions and in other areas of social work practice were excluded. Papers had to report empirical research or be reviews of relevant research. Government papers, policy documents, theoretical material and descriptive case study articles were excluded. It became clear during scoping that a number of relevant empirical studies were available through dissertation publications by research students at Master's and Doctoral levels so grey literature was included. Extending the search to this type of grey literature reduces the potential for publication bias (Burdett et al, 2003) although it is recognised that this is less of an issue for social work than for some other areas of study (Egger et al, 2003, Taylor, Dempster and Donnelly, 2007). The studies selected were limited to English language (due to the high cost of translation) and a ten year time frame: $01^{\text {st }}$ January 2000 to $31^{\text {st }}$ December 2009.

\section{Development of Research Formulae}

The first step in developing the search formulae was to break the research question into the concept groups. These were "Resilience" or "Burnout" and "Retention" and "Turnover" in "Child Protection Social Work" or "Child Welfare". A standard structure for developing search criteria is suggested by Taylor et al $(2003,2006)$ which includes five broad thematic areas. Type of service or intervention (Social Work), aspect of service (child protection), client groups (children and families), professional role or task (child protection - related to "burnout" or "resilience" and "retention and turnover"), publication limits (English language, research based 
studies, including grey literature, ten year time frame). It is important that concept groups reflected the meaning of the terms so that retrieval of relevant articles could be achieved (high sensitivity) and then refined sufficiently (high precision) to minimise the number of irrelevant articles (Taylor et al, 2007). The concept groups were the beginning of the development of the search formulae that were used across all data bases and each database had variations on search terms to operationalize how the concept groups became search formulae.

The second step was to refine the search terms for maximum precision from each database. Electronic databases are electronic libraries that can be used to search for titles, authors, key words using "text terms". Bibliographic databases of journal articles have the additional ability of searching titles, abstracts, and full articles as well as work with a combination of terms developed from standard Boolean algebra (Taylor, 2003). Many of the databases used had the additional feature of thesaurus with index terms to assist in overcoming the range and variation of reflecting context specific search terms. For example, USA and Canada studies refer to "child welfare", whereas UK and Australian studies refer to "child protection”. Psych Info, Medline, ASSIA, Cochrane Library, CINAHL, and Social Care Online have systems for indexing terms. Social Services Abstracts, SSCI, Index to Thesis, ZETOC and Google Scholar did not have this facility. Proximity searching was a feature of CINAHL, Medline, SSA, Psych Info and SSCI. This feature adds to precision as it allows for a search of two or more terms within a certain number of words of each other. For example, "child protection adj4 burnout" searches for child protection and burnout within four words of each other. 


\section{Individual Themes \\ Personal History of Maltreatment}

Researchers have investigated the extent of trauma histories in professionals such as social workers, due to concerns that the personal abuse histories of these professionals may lead to the experience of trauma symptoms, counter-transference, vicarious traumatisation and burnout as a result of continued exposure to traumatic material (Follette et al., 1994, cited in Stevens and Higgins, 2002). Five studies in the current literature review highlight a relationship between personal history of maltreatment and burnout or vicarious traumatisation (Cunningham, 2003; Nelson-Gardel and Harrris, 2003; Bride, 2007; Shepel, 2009; Stevens, 2002. Bride (2007) found that a personal history of childhood trauma increases a child welfare worker's risk of secondary traumatic stress (STS). Results are consistent with other studies that indicate a personal trauma history, especially in childhood as a significant risk factor in the development of STS (Caringi, 2008, Nelson-Gardell and Harris, 2003).

Whether a history of trauma will enhance one's resilience or reduce it is a matter for further research. Stevens and Higgins (2002:323) point out that the considerable disparity of reported prevalence rates of abuse histories among those in the 'helping professions' (7.1\% to $83 \%$ ) reflects differences in sampling, content, definitions, format techniques and random variation. Furthermore, the authors acknowledge the significance of personal abuse history as a possible motivator to enter the caring professions and suggest that organizational strategies should be developed to foster resilience in these employees. 


\section{Training and Preparation for Child Welfare}

Studies that have focused on training and preparation issues include Rosenthal, 2006; Ellett, 2006; Ellett et al., 2009; Curry, 2005; Turcotte, 2009. Rosenthal, (2006) in a large-scale study of 839 workers found that participation in funded social work education programmes predicted increased retention. Title IV is a USA Government based strategy between employers and educators in order to attract and retain recruits in child welfare. The scheme involves a stipend payment to students in return for a commitment to remain in the job for a pre-allocated time period beyond qualifying as a social worker (Rosenthal, 2006). Ellett (2006) conducted a study with 369 participants and also reported that a clear retention factor was IV-E internship, internship experiences or work experience in child welfare before taking the job.

Ellett et al, (2009) describes the development and initial implementation of an Employee Selection Programme (ESP) for child welfare. The results of this study highlighted the benefit of ESP in improving the employee selection process and how this assisted retention of the considerable financial and human investments in making employee decisions. There is a professional responsibility on staff to engage in ongoing CPD (Continuous Professional Development), not just for ethical and governance reasons, but for the growth of professional knowledge and skills and also to maintain professional registration status (Munro, 2011). Research by Curry (2005) has identified transfer of learning factors and the impact of overall knowledge-transfer and suggests that these findings support the need for training and development opportunities as part of a holistic staff retention programme. Furthermore, Turcotte (2006) found that following the implementation of a training programme, a large 
sample of 945 practitioners felt more competent, had acquired additional knowledge and had changed some of their behaviours with families.

\section{Coping}

Coping with the demands of the job were discussed in a number of studies. Eight studies were identified as belonging to this category (Anderson, 2000; AclaroLapidario, 2008; Nissley, 2004; Nordick, 2002; Robichaud, 2004; Vu Paul Hoang, 2007; McGowan, 2009; Weuste, 2006. Nordick (2002) found that social workers achieved balance, surviving, thriving, job satisfaction, job retention, self-actualization as well as meaning and purpose with work by using a number of coping strategies. These methods include (1) applying investigative and interpersonal skills, (2) embracing the risks and challenge, (3) finding meaning and purpose, (4) expect the unexpected, (5) keep expectations realistic, (6) achieve competence and confidence, (7) find support from others and supervision, (8) maintaining an important life outside work, (9) debriefing from trauma, (10) learning about self and self-awareness.

Anderson (2000) examined how 151 Social Workers with at least 2 years' experience coped with job stress. The findings of the study showed that participants view themselves as using active coping strategies such as cognitive restructuring and problem solving, more than expressing emotions and social support. These strategies were used more than problem avoidance, self-criticism or social withdrawal. The findings confirm that coping strategies that are used vary according to the level of burnout experienced. According to these findings, workers should use active coping 
strategies such as emotion focused coping methods and support from colleagues to prevent and treat their experiences of emotional exhaustion.

Aclaro-Lapidario (2008) conducted a study with 75 child welfare staff to measure compassion satisfaction (CS), burnout (BO) and secondary traumatic stress (STS). Findings revealed that pleasure from helping others was one of the main sources of maintaining workers in their role. Interestingly, the top three reported coping mechanisms were "talking to a co-worker or spouse", "exercising" "lunch/dining out" (Aclaro-Lapidario, 2008:44). This study confirms the findings of Anderson (2000), that burnout is less likely when active coping is engaged.

\section{Job Satisfaction and Dissatisfaction}

Despite the knowledge of the levels of burnout and turnover in child protection social work, there is evidence that some individuals "love" this profession (Nordick, 2002:3), thrive in the job and wish to remain employed in this sector (Stalker et a;., 2007). Four articles were categorised as relevant to the discussion of job satisfaction and dissatisfaction and report on the factors found to be prevalent for both ends of this continuum (Stalker et al., 2007; Nordick, 2002; Szu Chen, 2009; Cahalane, 2008). These studies reflect a common thread, sometimes with conflicting findings, relating to the experience of working in child welfare which include the individual's tendencies towards emotional arousal, cognitive problem solving, emotional exhaustion, self-efficacy and coping. 
Stalker, et al., (2007) conducted a systematic literature review of 6 studies that assessed the co-existence of job satisfaction (JS) and emotional exhaustion (EE) in samples of child welfare employees. Results reveal that $47 \%$ of participants were highly satisfied with their job yet the mean of the EE scores were recorded in the high range (Maslach Burnout Inventory, MBI, Maslach and Jackson, 1996). The research questions used to guide these studies were varied which could explain why a correlation between emotional exhaustion and job satisfaction had not always been reported. Methodological design limitations such as the use of non-validated measures were found and in many studies job satisfaction had been measured by a single question. Other findings are in contrast to Stalker, et al., (2007) regarding the co-existence of high EE and JS. For example, the Szu Chen (2009) study reported on longitudinal quantitative research with 455 participants. The main objective of this study was to examine the influence of job satisfaction on worker's desire to remain in this sector. Findings show that improving job satisfaction is not the only factor of importance in retaining staff. Similarly, Coleman's (2003) study with 550 Title IV MSW child welfare students, found that those at higher levels of cognitive affective levels should be less prone to burnout and able to make tough social work decisions which are necessary of this profession. These workers are also more able to use insights from own emotions and the emotions of others to inform practice.

\section{Organizational Themes}

\section{Organizational and Professional Commitment}

Commitment to child welfare has been shown to have strong significance on whether an employee stays or leaves the child welfare profession. Fourteen studies touch upon 
this variation of the theme (DePanfilis, 2008; Mor Barak, et al., 2001; Mor Barak, 2006; Barth, 2001; Strolin-Goltzman, 2008; Landsman, 2008; O’Donnell, 2009; Stalker, 2007; McGowan, 2009; Chernesky, 2009; Yankeelov 2009; Szu Chen 2009; Ellett, et al., 2003; Song Ki Bum, 2006). DePanfillis (2008) found the importance of worker commitment to the profession, showing low levels of worker exhaustion and high levels of self-efficacy for staying and co-worker support, salary and benefits as important organizational factors that impact on retention.

Using longitudinal methods O'Donnell (2009) found that the most consistent factor relating to whether the sample of 201 MSWs (Master in Social Work) stayed past their Title IV stipend commitment was organizational commitment. Similarly, a cross sectional survey conducted by Chernesky (2009) examined reasons for taking a public child welfare job as well as job expectations to understand why workers leave. Findings revealed that workers who form a certain attachment to their supervisors and take jobs because they are committed to the mission of the agency were more satisfied and less inclined to leave.

Weaver (2007) examined predictors of turnover amongst newly qualified child welfare workers. This study was based on 141 "leavers" and 382 "still in post". Results distinguish "intention to leave", versus "actually leaving". It was found that attitudes of staff to job conditions are more likely to be associated with intention to leave than job exit. Collectively, these studies indicate that workers first of all need to feel committed to the agency, have formed an attachment to their supervisors and have a positive perception about job conditions in order to promote their retention. 


\section{Organizational Culture and Climate}

Studies have looked at organizational climate as key to the issue of turnover and retention in child welfare organizations (Bednar, 2003; Mor Barak, 2006; Cahalane, 2008; Chenot, 2008; Glisson, 2006; Healy et al., 2009; Kyonne, 2009; Landsman, 2007; Barth, 2006; Strolin-Goltzman et al.. 2008). Supervisory support, level of trust between colleagues and adequate resources all correlated with job satisfaction. Furthermore, organizational climate can also impact on service quality and service user outcomes and climate was found to be the primary predictor of positive outcomes for children (Glisson and Hemmelgarn (1998), cited in Bednar (2003). Kyonne's (2009) study used secondary quantitative data relating to 310 child welfare staff. Findings indicated that the workers' positive perception of teamwork decreased their stated intentions to leave whereas the workers' burnout increases their stated intentions to leave.

Chenot (2008) found that a passive defensive organizational culture has a negative impact on early career workers, but not on those in mid or late career stages. This suggests that there is a reduction in sensitivity to passive defensive organizational culture evident over time. Support and organizational culture has only a limited impact on retention across varying stages of child welfare workers careers. Healy et al. (2009) carried out a comparative study across three countries, England, Sweden and Australia focusing on the analysis of barriers to retaining novice practitioners. This study confirmed that the absence of line management support together with the level of inexperience in teams and a lack of peer support exacerbates the situation for novices. 
In a study by Strolin-Goltzman et al. (2008), intention to leave and actual turnover were measured following the evaluation of an intervention designed to address organizational causes of turnover in public child welfare. Findings support the use of Design Teams (DTs) as a method of achieving organizational change that positively facilitates workforce retention in child welfare. The study found changes to be at agency and individual level with a significant decrease on intention to leave and an improvement in organizational commitment and actual turnover levels. Qualitative findings suggest that self-sustaining agencies were managed by strong leaders who possessed professional characteristics and organizational conditions that contributed to sustaining DTs. However, it is possible that those organizational conditions were the factors that led it to participate, in the first instance.

\section{Workload}

Workload is acknowledged as a significant stressor in child protection work by a number of research studies (Dillenberger, 2004; Ellett, 2006; Juby and Scannapieco, 2007; Stalker, 2007; Tham and Meagher, 2009; Strand, 2009; Van Hook, 2009). High workload and low wages have been confirmed as impacting negatively on workers' self-esteem. In a large scale quantitative study Strand (2009:395) found that such conditions indicates to staff that they are not valued by their employer. Furthermore, workers perceive such working conditions to indicate that their welfare is not important to their employer, which in turn results in a lack of organizational commitment and high rates of attrition. Excessive working hours were found in a study by Ellett (2006) which records that both the front line workers and their supervisors have to work 50-60 hours per week and in some cases 70 hours per week. 
Comparing the specific experiences of child welfare workers $(n=309)$, with social workers more generally and human service workers on a larger scale $(22,532)$, Tham and Meagher (2009) found that whilst child welfare workers made positive assessments of some dimensions of their working lives, their job was unusually demanding compared to other human services workers.

\section{Peer and Management Support}

Social support and supervision has been found to contribute to worker retention in a number of studies (Nissly, 2002; 2005; Stevens and Higgins, 2002; Yankeelov, 2009; Westbrook, 2006; Szu Chen, 2009; Nordick, 2002; Curry, et al. 2005; Mor Barak, 2001; Barth, 2008; Anderson, 2000). Research on turnover has repeatedly shown that supervisor and co-worker support can buffer the effect of burnout and turnover (Curry et al., 2005; Smith, 2005; Weaver et al., 2007; Mor Barak, 2001).

Using longitudinal methods, Scannapieco (2007) confirmed that co-workers and supervisors play a crucial role in the retention of staff. Anderson (2000) similarly found that active coping mechanisms and social supports protect against burnout. Yankeelov (2009) reported that stayers were more attached to their supervisors and received more guidance and suggests that a supportive relationship with supervisors can provide a secure and buffering effect to protect staff from the stresses of the job. Research on turnover has repeatedly shown that supervisor and co-worker support can buffer the effect of burnout and turnover (Curry et al., 2005; Smith, 2005; Weaver, et al., 2007; Mor Barak, 2001). DePanfilis (2006) carried out a literature review of 25 
studies and concluded that child welfare managers need to be aware of their important and significant role in helping workers to deal effectively with secondary trauma.

Dickenson's (2009) experimental retention study based on 151 child welfare staff highlights the concept of "undesirable exits". Results strongly indicate that supervisor practice support can significantly and incrementally decrease a workers risk of leaving. Strand (2009) similarly found that the more satisfaction with supervision, working conditions, availability of both internal and external resources, and/or being a manager, created more job satisfaction.

\section{STS, Compassion Satisfaction and Compassion Fatigue}

Five studies focused on secondary traumatic stress (STS) or compassion fatigue/satisfaction $(\mathrm{CF} / \mathrm{S})$ and the impact on workers of dealing with traumatic aspects of child protection work on a daily basis (Bride, 2007; Conrad and KellarGuenther, 2006; Aclaro-Lapidario, 2007; Caringi, 2008; Van Hook, 2009). The effects of traumatic events are not solely confined to those who directly experience them. The term STS is applied to those who have regular contact with traumatised individuals. Such individuals can experience prolonged emotional disruption and become indirectly affected by the trauma (Figley, 1995, cited in Conrad and KellarGuenther, 2006).

Many studies have noted that child protection workers are especially at risk for the development of STS given their level of contact with abused children (Bell, Kulkarni, and Dalton, 2003; Horwitz, 1998; Cornille and Myers, 1999; Meyers and Cornille, 
2002, all cited in Conrad and Kellar-Guenther, 2006), found that child protection workers suffered from more psychological distress than the general population, and many had distress levels greater than those reported by typical outpatient mental health clients.

Caringi (2008) conducted a study into STS to understand the impact of this on a sample of 102 child protection workers. He was also interested in understanding the mitigating and contributing factors that are associated with STS. Mitigating factors were, (1) prior personal history of worker trauma, (2) coping style, (3) organizational factors, (4) workers own perception of stress. This research tends to confirm the findings that $\mathrm{CF}$ is evident in the child protection workforce with mitigating factors that need to be considered.

\section{Discussion}

This paper attempts to bring together a range of current research findings on resilience and burnout in child protection social work. A career time line perspective was useful to examine relevant factors and allow cognisance of individual and organizational factors that need to be considered in relation to the individual worker experience in this important role. Resilience and burnout outcomes are related to a range of factors to be considered which are associated with individual issues and/or training or employee context and organizational dimensions or experiences.

It is first of all important to consider the individual worker motivation to be a social worker, taking into account the "personal history of maltreatment" discussion and 
how such a history impacts on workers who are dealing with vicarious trauma of others on a daily basis. The results from this review suggest that personal awareness and personal development are important at the point of entry onto this career, for individuals and educators as well as employers and this commitment should be a career long activity. Although it cannot be assumed that all motivation to a social work career has an origin in a personal history of trauma, consideration could be universally applied to promote a mind set to support workers who have had such a history. There should be consideration on many aspects relating to training at undergraduate and post graduate levels. Specifically, it is recommended that practice placements and preparation for practice should reflect the demands, challenges and realities of the job.

Coping styles are also important to consider in relation to any recommendations to improve worker resilience around the challenges of the job. According to Anderson, (2000), those who use active and engaged coping methods such as cognitive restructuring and problem solving coped better with the demands of the job than those who use avoidant or disengaged methods such as withdrawal and absenteeism. Therefore, coping methods and professional development strategies could become integrated into undergraduate and post qualifying training to enhance worker resilience. One might argue that those with a previous history of maltreatment have either enhanced coping mechanism or, on the other hand, their ability to cope may have been compromised (Shepel, 2009). The outcome for such workers is highly individual and will depend on the meaning they have applied to their experiences and any therapeutic interventions to process the event/s. This suggests the need for individuals to develop internal resilience by engaging in personal and professional 
development strategies from the outset of their career so that they can build on these to develop active coping methods and practices.

Organizational and professional commitment has been discussed in the context of studies examining workers intention to stay or leave. The overwhelming finding from these studies is that supervisory and peer supports are significant factors which influence commitment, organizational culture and intention to stay or leave (Stalker, 2007; Strolin-Goltzman, 2008; Yankeelov, 2009; Schwartz, 2008; Bednar, 2005; Barak, 2006; Cahalane, 2008; Glisson, 2008; Kyonne, 2009; Landsman, 2007; Barth, 2006; Juby and Scannapieco, 2007). Organizational culture is experienced by workers as either positive or negative during their career. Recommendations are targeted at employer level and call for an examination of culture and climate contributors, specifically the quality of manager support and supervision, and the factors that impact on the contextual work experiences for staff. For example, studies confirm that a major contributor to burnout is workload and staff being stretched beyond capacity (Dillenburger, 2004; Ellett, 2006; Juby Scannapieco, 2007; Stalker, 2007; Tham and Meagher, 2009; Strand, 2009; Van Hook, 2009). In addition, commitment is closely related to turnover or retention of staff and according to DePanfilis (2008) and Mor Barak et al., (2001) factors that create commitment is within the grasp of managers and policy makers to manipulate. These authors state that the major predictors of turnover are not individual but are work and organizational based, therefore there is more that could be done to increase job satisfaction and reduce attrition in this sector. It is recommended that employers and policy makers consider the significant factors that are evidenced to contribute to turnover and develop a strategic approach to build resilience into the workforce. 


\section{Conclusion}

The themes that contribute to resilience are discussed drawing from the range of studies in this literature review include positive coping styles and personal development, good quality primary and ongoing training, constructive organizational cultures, supportive social and supervisory support, together with manageable workloads. Whereas, defensive organizational culture with poor social supports and unmanageable case loads are related to intention to leave and job exit. StrolinGoltzman (2008) argues that low turnover is not always indicative of a healthy organization and a lack of job alternatives could be a more realistic reason why workers remain. This is a very important issue in the current economic and employment downturn.

The information retrieved from the included 65 studies provides an overview of the issues relevant to the maintenance of staff and to help them to achieve longevity in a very difficult and stressful occupation which requires them to protect children and young people in society. The results have produced a framework which has formed the basis of an empirical research programme on the individual and organizational factors that lead to certain outcomes regarding retention or turnover of staff in this sector. This could go a long way towards providing an evidence base for policy and practice regarding the retention of staff and practice experience in this critical area of social work. 


\section{REFERENCES}

Aclaro-Lapidario, M. L.,. (2008) 'Coping strategies of children's social workers in the Department of Children and Family Services (California)', Masters Abstracts International , 46(02), pp. 0730-0730.

Anderson, D. G. (2000) 'Coping Strategies and Burnout among Veteran Child Protection Workers', Child Abuse and Neglect, 24(6), pp. 839-848.

Barak, M. E. M., Levin, A., Nissly, J. A. and Lane, C. J. (2006) 'Why do they leave? Modeling child welfare workers' turnover intentions', Children and Youth Services Review, 28(5), pp. 548-577.

Barak, M. E. M., Nissly, J. A. and Levin, A. (2001) 'Antecedents to retention and turnover among child welfare, social work, and other human service employees: What can we learn from past research? A review and metanalysis', Social Service Review , 75(4), pp. 625-661.

Barth, R. P., Lloyd, E. C., Christ, S. L., Chapman, M. V. and Dickinson, N. S. (2008) 'Child Welfare Worker Characteristics and Job satisfaction: A National Study', Social work, 53(3), pp. 199-209.

Bednar, S. G. (2003) 'Elements of satisfying organizational climates in child welfare agencies', Families in Society-the Journal of Contemporary Human Services, 84(1), pp. 7-12.

Bride, B. E., Radey, M. and Figley, C. R. (2007) 'Measuring Compassion Fatigue', Clinical Social Work Journal, 35(3), pp. 155-163. 
Cahalane, H. and Sites, E. W. (2008) 'The Climate of Child Welfare Employee Retention', Child welfare, 87(1).

Caringi, J. C. (2008) 'Secondary traumatic stress in New York State child welfare workers', Dissertation Abstracts International, A: The Humanities and Social Sciences, 68(10), pp. 4476-4476.

Chen, S. and Scannapieco, M. (2010) 'The influence of job satisfaction on child welfare worker's desire to stay: An examination of the interaction effect of self-efficacy and supportive supervision', Children and Youth Services Review, 32(4), pp. 482-486.

Chenot, D., Benton, A. D. and Kim, H. (2009) 'The Influence of Supervisor Support, Peer Support, and Organizational Culture Among Early Career Social Workers in Child Welfare Services', Child welfare, 88(5), pp. 129148.

Chernesky, R. H. and Israel, M. K. (2009) 'Job Expectations and Intention to Leave in a State Child Welfare Agency', Journal of Public Child Welfare, 3(1), pp. 23-39.

Coleman, D. and Clark, S. (2003) 'Preparing for Child Welfare Practice: Themes, a Cognitive-Affective Model, and Implications from a Qualitative Study', Journal of Human Behavior in the Social Environment , 7(1-2), pp. 83-96. 
Conrad, D. and Kellar-Guenther, Y. (2006) 'Compassion fatigue, burnout, and compassion satisfaction among Colorado child protection workers', Child abuse \& neglect, 30(10), pp. 1071-1080.

Cunningham, M. (2003) 'Impact of Trauma Work on Social Work Clinicians: Empirical Findings', Social work, 48(4), pp. 451-459.

Curry, D., McCarragher, T. and Dellmann-Jenkins, M. (2005) 'Training, transfer, and turnover: Exploring the relationship among transfer of learning factors and staff retention in child welfare', Children and Youth Services Review, 27(8), pp. 931-948.

DePanfilis, D. and Zlotnik, J. L. (2008) 'Retention of front-line staff in child welfare: A systematic review of research', Children and Youth Services Review, 30(9), pp. 995-1008.

Dickinson, N. S. and Painter, J. S. (2009) 'Predictors of undesired turnover for child welfare workers.', Child welfare, 88(5), pp. 187-208.

Dillenburger, K. (2004) 'Causes and Alleviation of Occupational Stress in Child Care Work', Child Care in Practice, 10(3), pp. 213-224.

Ellett, A. J. (2009) 'Intentions to remain employed in child welfare: The role of human caring, self-efficacy beliefs, and professional organizational culture', Children and Youth Services Review, 31(1), pp. 78-88.

Ellett, A. J., Ellett, C. D., Ellis, J. and Lerner, B. (2009) 'A Research-Based Child Welfare Employee Selection Protocol: Strengthening Retention of the Workforce', Child welfare, 88(5), pp. 49-68. 
Ellett, A. J. S. (2001) 'Human Caring, Self-Efficacy Beliefs, and Professional Organizational Culture Correlates of Employee Retention in Child Welfare', Dissertation Abstracts International, A: The Humanities and Social Sciences , 61(8), pp. 3350-A-3351-A.

Gibbs, J. A. (2001) 'Maintaining Front-Line Workers in Child Protection: A Case for Refocusing Supervision', Child Abuse Review, 10, pp. 323-335.

Glisson, C., Dukes, D. and Green, P. (2006) 'The Effects of the ARC Organizational Intervention on Caseworker Turnover, Climate, and Culture in Children's Service Systems', Child abuse \& neglect, 30(8), pp. $855-880$.

Healy, K., Meagher, G. and Cullin, J. (2009) 'Retaining Novices to Become Expert Child Protection Practitioners: Creating Career Pathways in Direct Practice', British Journal of Social Work, 39(2), pp. 299-317.

Juby, C. and Scannapieco, M. (2007) 'Characteristics of Workload Management in Public Child Welfare Agencies', Administration in Social Work, 31(3), pp. 95-109.

Kyonne, J. (2009) 'The role of teamwork in public child welfare caseworkers' intentions to leave', Dissertation Abstracts International, A: The Humanities and Social Sciences, 70(04), pp. 1429-1429.

Landsman, M. J. (2001) 'Commitment in public child welfare', Social Service Review, 75(3), pp. 386-419. 
Landsman, M. J. (2008) 'Pathways to organizational commitment', Administration in Social Work, 32(2), pp. 105-132.

Maslach C, Jackson S, Leiter M, 1996, Maslach Burnout Inventory Manual $\left(3^{r d} E d\right)$ Wiley \& Sons Inc. CA

McGowan, B. G., Auerbach, C. and Strolin-Goltzman, J. S. (2009) 'Turnover in the Child Welfare Workforce: A Different Perspective', Journal of Social Service Research, 35(3), pp. 228-235.

The Munro Review of Child Protection: A child centred system. (May 2011)

Nelson-Gardell, D. and Harris, D. (2003) 'Childhood Abuse History, Secondary Traumatic Stress, and Child Welfare Workers', Child welfare, 82(1), pp. 5-26.

Nissly, J. A., Barak, M. M. and and Levin, A. (2004) 'Stress, Social Support, and Workers' Intentions to Leave Their Jobs in Public Child Welfare', Administration in Social Work, 29(1), pp. 79-100.

Nordick, W. G. (2002) 'Striking balance, enjoying challenge : how social workers in child protection stay on the high wire', $U B C$ Retrospective Theses Digitization Project [http://www.library.ubc.ca/archives/retro theses/] , .

O'Donnell, J. and Kirkner, S. L. (2009) 'A Longitudinal Study of Factors Influencing the Retention of Title IV-E Master's of Social Work Graduates in Public Child Welfare', Journal of Public Child Welfare, 3(1), pp. 64-86. 
Perrone, R. V. (2007) 'The impact of burnout, job satisfaction and work environment on child welfare family case managers.', Dissertation Abstracts International Section A: Humanities and Social Sciences, 67(12-A), pp. 4702.

Robichaud, C. M. (2004) 'The Relationship of Spirituality and Coping to Burnout in Child Welfare Workers', Dissertation Abstracts International, A: The Humanities and Social Sciences, 65(3), pp. 1122-A.

Rosenthal, J. A. and Waters, E. (2006) 'Predictors of child welfare worker retention and performance: Focus on title IV-E-funded social work education', Journal of Social Service Research, 32(3), pp. 67-85.

Scannapieco, M. and Connell-Carrick, K. (2007) 'Child welfare workplace: the state of the workforce and strategies to improve retention.', Child welfare, 86(6), pp. 31-52.

Schwartz, S. L. (2008) 'Engaging our workforce: How job demands and resources contribute to social worker burnout, engagement and intent to leave', Dissertation Abstracts International, A: The Humanities and Social Sciences, 68(07), pp. 3151-3151.

Shepel, L. M. (2009) 'Potential triple jeopardy: A descriptive cross-sectional study of the impact of vicarious traumatization and secondary traumatic stress on Aboriginal child welfare social workers', Dissertation Abstracts International, A: The Humanities and Social Sciences , 69(11), pp. 45084508. 
Smith, B. D. (2005) 'Job retention in child welfare: Effects of perceived organizational support, supervisor support, and intrinsic job value', Children and Youth Services Review, 27(2), pp. 153-169.

Song, K. (2006) 'Prevelance of Client Violence toward Child and Family Social Workers and Its Effects on Burnout, Organizational Commitment, and Turnover Intention: A Structural Equation Modelling Approach', Dissertation Abstracts International, A: The Humanities and Social Sciences, 66(9), pp. 3465-A.

Stalker, C. A., Mandell, D., Frensch, K. A., Harvey, C. and Wright, M. (2007) 'Children welfare workers who are exhausted yet satisfied with their jobs: how do they do it?', Child \& Family Social Work, 12(2), pp. 182-191.

Stevens, M. and Higgins, D. J. (2002) 'The Influence of Risk and Protective Factors on Burnout Experienced by Those Who Work with Maltreated Children', Child Abuse Review, 11(5), pp. 313-331.

Strand, V. C. and Dore, M. M. (2009) 'Job satisfaction in a stable state child welfare workforce: Implications for staff retention', Children and Youth Services Review, 31(3), pp. 391-397.

Strolin-Goltzman, J., McCarthy, M., Smith, B., Caringi, J., Bronstein, L. and Lawson, H. (2008) 'Should I stay or should I go? A comparison study of intention to leave among public child welfare systems with high and low turnover rates', Child Welfare, 87(4), pp. 125-143. 
Tham, P. and Meagher, G. (2009) 'Working in Human Services: How Do Experiences and Working Conditions in Child Welfare Social Work Compare?', British Journal of Social Work, 39(5), pp. 807-827.

Turcotte, D., Lamonde, G. and Beaudoin, A. (2009) 'Evaluation of an InService Training Program for Child Welfare Practitioners', Research on Social Work Practice, 19(1), pp. 31-41.

Turcotte, D. and Pouliot, E. (2006) 'Job satisfaction of social workers in child protection', Canadian Social Work, 8(1), pp. 46-46.

Van Hook, M. P. and Rothenberg, M. (2009) 'Quality of Life and Compassion Satisfaction/Fatigue and Burnout in Child Welfare Workers: A Study of the Child Welfare Workers in Community Based Care Organizations in Central Florida', Social Work \& Christianity, 36(1), pp. 36-54.

Vu, P. H. (2007) 'Perceived coping strategies of children's social workers in dealing with vicarious trauma', Masters Abstracts International , 45(05), pp. $2280-2280$.

Weaver, D., Chang, J., Clark, S. and Rhee, S. (2007) 'Keeping Public Child Welfare Workers on the Job', Administration in Social Work, 31(2), pp. $5-25$.

Westbrook, T. M., Ellis, J. and Ellett, A. J. (2006) 'Improving retention among public child welfare workers: What can we learn from the insights and experiences of committed survivors?', Administration in Social Work, 30(4), pp. 37-62. 
Weuste, M. B. (2006) 'Critical Incident Stress and Debriefing of Child Welfare Workers', Dissertation Abstracts International, A: The Humanities and Social Sciences, 66(7), pp. 2727-A.

Yankeelov, P. A., Barbee, A. P., Sullivan, D. and Antle, B. F. (2009) 'Individual and organizational factors in job retention in Kentucky's child welfare agency', Children and Youth Services Review, 31(5), pp. 547-554. 
Table on themes found in systematic literature review: Resilience and Burnout in Child Protection Social Work

\begin{tabular}{|c|c|c|c|c|}
\hline No & $\begin{array}{l}\text { Author } \\
\text { Year and } \\
\text { Country }\end{array}$ & Data-Base & Factors Identified - Verbatim extracts from studies. & $\begin{array}{l}\text { Methodology } \\
\text { Studies are of those workers in post unless otherwise stated.master final data } \\
\text { ext table } 65 \text { july 2013.doc }\end{array}$ \\
\hline 1 & $\begin{array}{l}\text { Aclaro- } \\
\text { Lapidario } \\
2008 \\
\text { USA }\end{array}$ & $\begin{array}{l}\text { ASSIA } \\
\text { SSA }\end{array}$ & $\begin{array}{l}\text { - } \quad \text { Compassion Satisfaction (CS), Burnout (BO), and Secondary } \\
\text { Traumatic Stress (STS) were not associated with total years of service } \\
\text { or size of caseload. } \\
\text { - } \quad \text { Marital status had a significant relationship with STS. } \\
\text { - } \quad \text { Fins reported using active coping to deal with stress. } \\
\text { prevention of the pernicious effects of STS. }\end{array}$ & $\begin{array}{l}\text { Survey. Quantitative study. Cross sectional survey design using non-probability } \\
\text { convenience sampling to measure CS, BO and STS. The Professional Quality of } \\
\text { Life scales and self-report questionnaires were administered to }(n=75) \text { workers. }\end{array}$ \\
\hline 2 & $\begin{array}{l}\text { Anderson } \\
2000 \\
\text { USA }\end{array}$ & $\begin{array}{l}\text { ASSIA } \\
\text { SSA }\end{array}$ & $\begin{array}{l}\text { - } \quad \text { Engaged coping = reduced DP and increased PA. } \\
\text { - } \quad \text { Nisengaged coping = EE and DP and reduced PA. } \\
\text { EE. } \\
\text { - The problem-focused strategies they are taught to use do not help them } \\
\text { deal with the emotional content \& context of their work, suggesting the } \\
\text { use of emotion-focused coping to prevent \& remediate burnout. }\end{array}$ & $\begin{array}{l}\text { Survey. Quantitative study - Cross sectional survey design, self report } \\
\text { questionnaires Inventory \& scale data are used to explore how ( } \mathrm{n}=151) \text { veteran } \\
(2+\text { years) front-line child protective service (CPS) investigations workers in a } \\
\text { south-eastern US social services department cope with job stress. The } \\
\text { relationship between coping strategies \& levels of emotional exhaustion, } \\
\text { depersonalization, \& sense of reduced personal accomplishment (burnout } \\
\text { syndrome) is also examined. Participants attended one of nine stress management } \\
\text { workshops provided in various locations around the state. }\end{array}$ \\
\hline 3 & $\begin{array}{l}\text { Barak } \\
2006 \\
\text { USA }\end{array}$ & SSCI & $\begin{array}{l}\text { Diversity, together with a stressful, unjust, exclusionary and non- } \\
\text { supportive organizational climate, negatively influences individual } \\
\text { wellbeing, job satisfaction and organizational commitment, resulting in } \\
\text { intention to leave the job. } \\
\text { - Study findings hold implications for supervisory recruitment and } \\
\text { training, structural and procedural systems reform. }\end{array}$ & $\begin{array}{l}\text { Mixed Methods. The study employed a cross-sectional design with mixed } \\
\text { method - both qualitative and quantitative - analyses, utilizing an availability } \\
\text { sample of } 418 \text { child welfare workers drawn from a large, urban public agency. } \\
\text { Mixed methods using SEM and constant content comparative analysis testing } \\
\text { theoretical model of intention to leave. }\end{array}$ \\
\hline 4 & $\begin{array}{l}\text { Barak } \\
2001 \\
\text { USA }\end{array}$ & SSCI & $\begin{array}{l}\text { Burnout, job dissatisfaction, availability of employment alternatives, } \\
\text { low organizational and professional commitment, stress, and lack of } \\
\text { social support are the strongest predictors of turnover or intention to } \\
\text { leave. } \\
\text { The major predictors of leaving are not personal or related to the } \\
\text { balance between work and family but are organizational or job based. }\end{array}$ & $\begin{array}{l}\text { Literature Review. Meta-analysis of } 25 \text { articles relating to child protection } \\
\text { social workers and other human services employees. }\end{array}$ \\
\hline 5 & $\begin{array}{l}\text { Barth } \\
2008 \\
\text { USA }\end{array}$ & SSCI & $\begin{array}{l}\text { Worker satisfaction is associated with quality of supervision and urban } \\
\text { setting but does not have a clearly in-dependent relationship with } \\
\text { having a degree in social work. }\end{array}$ & $\begin{array}{l}\text { Survey. Quantitative survey on child and adolescent wellbeing also collected } \\
\text { information on child welfare workers satisfaction }(n=1729) \text {. }\end{array}$ \\
\hline 6 & $\begin{array}{l}\text { Bednar } \\
2003 \\
\text { USA }\end{array}$ & SSCI & $\begin{array}{l}\text { This review examines research on Job satisfaction in child welfare } \\
\text { systems and on factors that influence a worker's decision to leave a job } \\
\text { or stay, as well as organizational climate factors which have been } \\
\text { linked to job satisfaction, consumer satisfaction, and client outcomes. }\end{array}$ & Literature review. \\
\hline
\end{tabular}




\begin{tabular}{|c|c|c|}
\hline 7 & $\begin{array}{l}\text { Bride } \\
2007 \\
\text { USA }\end{array}$ & $\begin{array}{l}\text { GS } \\
\text { CIN }\end{array}$ \\
\hline 8 & $\begin{array}{l}\text { Cahalane } \\
2008 \\
\text { USA }\end{array}$ & $\begin{array}{l}\text { ASSIA } \\
\text { Med } \\
\text { CIN }\end{array}$ \\
\hline 9 & $\begin{array}{l}\text { Caringi } \\
\text { Strolin- } \\
\text { Goltzman, } \\
\text { Lawson, } \\
\text { McCarthy, } \\
\text { Briar-Lawson } \\
\text { and Claiborne } \\
\text { 2008 } \\
\text { USA }\end{array}$ & $\begin{array}{l}\text { SSCI } \\
\text { ASSIA } \\
\text { P Info } \\
\text { CIN } \\
\text { GS }\end{array}$ \\
\hline 10 & $\begin{array}{l}\text { Chenot } \\
2008 \\
\text { USA }\end{array}$ & Med \\
\hline 11 & $\begin{array}{l}\text { Chernesky } \\
2009 \\
\text { USA }\end{array}$ & $\begin{array}{l}\text { SSCI } \\
\text { ASSIA }\end{array}$ \\
\hline 12 & $\begin{array}{l}\text { Coleman } \\
2003 \\
\text { USA }\end{array}$ & ASSIA \\
\hline
\end{tabular}

- Relationship between levels of secondary traumatic stress in CPS professionals and the group of potential correlates: personal history of trauma in the past year and lifetime, peer support, administrative support, intent to remain employed in child welfare, professional experience, and size of caseload

- Evidence suggests that efforts to retain highly skilled and educated public child welfare workers should focus on creating positive organizational climates within agencies.

- $\quad$ DT (Design Team) intervention potential contributions to social work education, research, and practice.

- Preliminary results from four systems in the DT intervention study indicate that from wave 1 (2002) to wave 2 (2005), the nonintervention systems showed a non-significant improvement of $3 \%$ on intention to leave $(\chi 2=1.530, d f=1, p=.27)$. At wave $1,81 \%$ of the employees identified an intention to leave, while $78 \% 1$ ) indicated intention to leave at wave 2 .

- The systems that received the DT intervention improved significantly by $22 \%$, from $76 \%$ down to $54 \%(\chi 2=4.432, d f=1, p<.05)$. The delta chi-square change suggests the between-group difference to be significantly different with $90 \%$ confidence that the change was not due to chance $(\Delta \chi 2=2.902, p<.10)$. These results offer promise regarding the efficacy of the DT intervention..

- Support and organizational culture has a varying degree of impact on retention (as the antidote for turnover) across different stages of CWS careers.

- Findings include the crucial role supervisor support plays in retaining workers not only in their agencies, but in the field of CWS.

- Passive defensive organizational culture has a negative effect on early career workers, but not on mid or late career workers. Suggesting that a unique sensitivity to passive defensive organizational cultures exists early in CWS workers' careers that dissipate over time.

- Workers who take jobs because they are committed to the mission of the agency were more satisfied and less inclined to leave.

- Regardless of why workers accepted the position, they were more likely to think about leaving if they thought the organization did not provide what they expected.

- These findings suggest that the reasons why workers choose to take a job in public child welfare may be as important as the reasons why workers choose to leave, and managers may need to consider workers' job expectations when addressing worker retention.

- The intense emotional challenge of child welfare work emerged in the focus groups. Cognitive-Affective Model.

- Several hypotheses for further research: that student at more advanced
Survey. Quantitative methodology. Data was collected by means of a webbased survey questionnaire. Participants were 187 child protection social workers. The study measured demographic variables, intention to remain employed (IRE-CW); secondary traumatic stress and organizational culture.

Survey. Quantitative survey of four different graduate cohorts $(n=305)$ over four year period. Mapping of those who remained in child welfare and those who left.

Action Research Pre (2002) post (2005) test of DT intervention. Secondary Traumatic Stress Scale was used to measure STS levels. The Social Work Education Consortium Demographics Survey used to gather demographic information. Three Likert scale questions were added to assess respondent's history of personal trauma. Semi-structured interview questions were utilized to gather data regarding perceived incidence, mitigating, and protective factors related to STS. Evaluation of an intervention to address the issue of workforce turnover and poor retention in child welfare. DT problem solving combines action research and learning. DTs and their facilitators rely on specially designed tools, protocols, research as they address retention related priorities.

Survey. Quantitative cross sectional survey $(\mathrm{n}=767)$ design, multi-level factor analysis

Survey. Cross sectional survey design examined reasons for taking a public child welfare position and job expectations to better understand why workers leave.

Qualitative research. Thirty-seven focus groups conducted over four years with approximately 550 Title IV-E MSW students in CA were submitted to qualitative thematic analysis. 


\begin{tabular}{|c|c|c|c|c|c|}
\hline & & & & $\begin{array}{l}\text { cognitive-affective levels should be less prone to burnout, better able } \\
\text { to make the difficult value-based decisions demanded by child welfare } \\
\text { work, \& more likely to integrate \& use the emotions of themselves \& } \\
\text { others. }\end{array}$ & \\
\hline 13 & $\begin{array}{l}\text { Conrad } \\
2006 \\
\text { USA }\end{array}$ & $\begin{array}{l}\text { ASSIA } \\
\text { SSA } \\
\text { SSCI } \\
\text { GS }\end{array}$ & • & - Compassion satisfaction may help mitigate the effects of burnout. & $\begin{array}{l}\text { Survey. A self-report instrument developed by Stamm and Figley was used to } \\
\text { measure the risk of compassion fatigue and burnout and the potential for } \\
\text { compassion satisfaction among } 363 \text { child protection staff participating in a } \\
\text { secondary trauma training seminar. }\end{array}$ \\
\hline 14 & $\begin{array}{l}\text { Cunningham } \\
2003 \\
\text { USA }\end{array}$ & $\begin{array}{l}\text { SSA } \\
\text { ASSIA }\end{array}$ & & $\begin{array}{l}\text { The effect on clinician's cognitive schemas \& the confounding } \\
\text { variables of personal history of abuse \& years' experience are } \\
\text { described. } \\
\text { Clinicians who worked primarily with clients who were sexually } \\
\text { abused reported more disruptions in cognitive schemas than clinicians } \\
\text { who worked with clients who had cancer. } \\
\text { These sub-groups are viewed as those who work with naturally } \\
\text { occurring trauma versus those who work with humanly induced } \\
\text { trauma, sexual abuse. }\end{array}$ & $\begin{array}{l}\text { Survey. This article describes a quantitative study of social work clinicians } \\
\text { working with two types of trauma: (1) the human-induced trauma, sexual abuse; } \\
\& \text { (2) the naturally caused trauma, cancer. The effect on clinician's cognitive } \\
\text { schemas \& the confounding variables of personal history of abuse \& years' } \\
\text { experience are described. (n=182, } 69 \% \text { of sample were those who work with } \\
\text { cancer patients and } 54 \% \text { sexual abuse workers). Measure was a questionnaire, } \\
\text { the Traumatic Stress Institute Belief Scale which measures the clinician's world } \\
\text { view and disruption to cognitive schemas. }\end{array}$ \\
\hline 15 & $\begin{array}{l}\text { Curry } \\
2005 \\
\text { USA }\end{array}$ & SSCI & & $\begin{array}{l}\text { The research identified transfer of learning factors and an indicator of } \\
\text { overall transfer support and explored their relationship to child welfare } \\
\text { social worker retention. } \\
\text { Transfer support, demographic variables (experience, age, education, } \\
\text { gender) and several transfer support factors (supervisory support, co- } \\
\text { worker support, application planning, caseload size) were identified as } \\
\text { predictors of retention. } \\
\text { The results provide support for the use of training and development } \\
\text { activities as part of comprehensive staff retention programs. } \\
\text { The results also raise additional questions about the ambiguous } \\
\text { relationship between training and turnover and suggest the need for } \\
\text { ongoing research in child welfare regarding training, transfer of } \\
\text { learning and staff retention. }\end{array}$ & $\begin{array}{l}\text { Longitudinal research study attempted to promote a better understanding of the } \\
\text { training, transfer, and turnover relationship. Transfer of learning factors were } \\
\text { used to predict staff retention among } 416 \text { child protective services workers who } \\
\text { participated in } 3 \text { phases of the study over a } 7 \text { year period. }\end{array}$ \\
\hline 16 & $\begin{array}{l}\text { DePanfilis } \\
2008 \\
\text { USA }\end{array}$ & $\begin{array}{l}\text { ASSIA } \\
\text { SSA } \\
\text { SSCI }\end{array}$ & & $\begin{array}{l}\text { Findings of this review reinforce the importance of workers' } \\
\text { commitment to child welfare, self-efficacy, and low levels of } \\
\text { emotional exhaustion as important personal factors for staying, } \\
\text { Supervisory and co-worker support and salary and benefits as } \\
\text { important organizational factors affecting retention. }\end{array}$ & $\begin{array}{l}\text { Literature Review. Analysis of research that used retention or turnover as the } \\
\text { dependent variable. Of the } 154 \text { documents identified, } 25 \text { were research studies } \\
\text { that focused on these variables. This paper focuses on reviewing the methods and } \\
\text { findings of nine studies that used multivariate analyses to explore the } \\
\text { relationships between organizational and/or personal factors as independent } \\
\text { variables and retention or turnover as dependent variables. }\end{array}$ \\
\hline 17 & $\begin{array}{l}\text { Dickenson } \\
2009 \\
\text { USA }\end{array}$ & Medline & & $\begin{array}{l}\text { Results of the first Cox regression analyses show that IL (Intention to } \\
\text { Leave) is a significant predictor of actual exit. } \\
\text { Supervisor practice support can decrease a worker's risk of exiting by } \\
42 \% \text { and that, for each year above the sample's average age of 36, risk } \\
\text { of undesired turnover is decreased by an additional } 4 \% \text {. } \\
\text { Important differences were also found according to degree type. A } \\
\text { worker with a BSW is } 75 \% \text { less likely to resign or be dismissed than a } \\
\text { worker with an MSW, and a worker with a BA is } 60 \% \text { less likely to }\end{array}$ & $\begin{array}{l}\text { Longitudinal Quantitative methods using survey questionnaire. Experimental } \\
\text { retention study using baseline demographic and attitudinal data collected from a } \\
\text { child welfare worker survey, combined with employment data from a human } \\
\text { resource database. Survival analyses and multilevel regression models identify } \\
\text { the strongest predictors of intent to leave and actual turnover ( } \mathrm{n}=157) \text {. }\end{array}$ \\
\hline
\end{tabular}




\begin{tabular}{|c|c|c|c|c|}
\hline & & & $\begin{array}{l}\text { experience an undesired exit than an MSW. } \\
\text { The survival graphs reveal that the risk of exiting tends to accelerate at } \\
\text { six months for MSW workers and again during the second year of } \\
\text { employment, followed by a period of relative job stability in year } \\
\text { three. } \\
\text { Close inspection of the predictor means for each degree subgroup } \\
\text { indicates that, while the prediction equation holds for workers with a } \\
\text { BA or BSW (i.e., exiting workers are younger and have poor } \\
\text { relationships with their supervisor), it does not hold for the MSW } \\
\text { group, where those exiting tend to be older. } \\
\text { Findings from Multilevel Linear Model (MLM) regression analysis } \\
\text { indicate that all variables except degree type are centred so that } \\
\text { individual scores represent one's relative standing above or below the } \\
\text { overall mean of that variable. } \\
\text { It is noteworthy that above average scores for the scales role clarity, } \\
\text { supervisor practice support, and organizational commitment reduce IL, } \\
\text { while above average scores on self-efficacy and growth and } \\
\text { advancement opportunities increase IL These findings suggest a } \\
\text { complex dynamic where multiple and sometimes competing forces are } \\
\text { at play. }\end{array}$ & \\
\hline 18 & $\begin{array}{l}\text { Dillenburger } \\
2004 \\
\text { UK }\end{array}$ & $\begin{array}{l}\text { ASSIA } \\
\text { SSCI }\end{array}$ & $\begin{array}{l}\text { The findings showed that social workers experience more stress than } \\
\text { would be expected in the general population. Consistent with a } \\
\text { Demand-Control-Support model, this was mainly caused by high } \\
\text { workloads, high staff turnover, and insufficient leadership and support. } \\
4 \text { Tables, } 26 \text { References. Adapted from the source document. }\end{array}$ & $\begin{array}{l}\text { Survey questionnaire distributed to field social workers in family and child care } \\
(\mathrm{n}=16) \text {. }\end{array}$ \\
\hline 19 & $\begin{array}{l}\text { Ellett, Ellett, } \\
\text { Ellis and } \\
\text { Lerner } \\
2009 \\
\text { USA }\end{array}$ & SSCI & $\begin{array}{l}\text { Using the ESP, applicants and employers make informed decisions } \\
\text { about the goodness of fit between the applicant and the demands of a } \\
\text { career in child welfare. (Employee Selection Protocol). Of particular } \\
\text { interest is the role that the ESP can play in improving the employee } \\
\text { selection process; conserving the considerable human and financial } \\
\text { investments in making employment decisions; and enhancing } \\
\text { employee retention rates by hiring better qualified child welfare } \\
\text { employees. }\end{array}$ & $\begin{array}{l}\text { Action Research. Evaluation of Employment Selection Programme. This } \\
\text { article describes the development and initial implementation of a new employee } \\
\text { selection protocol (ESP) for child welfare grounded in the results of recent large- } \\
\text { scale employee retention studies and a set of research-based, minimally essential } \\
\text { knowledge, skills, abilities, and values. The complete ESP consists of a } \\
\text { sequenced set of Web- and site-based assessment processes and procedures for } \\
\text { potential applicants. Using the ESP, applicants and employers make inforMed } \\
\text { decisions about the goodness of fit between the applicant and the demands of a } \\
\text { career in child welfare. }\end{array}$ \\
\hline 20 & $\begin{array}{l}\text { Ellett } \\
2009 \\
\text { USA }\end{array}$ & $\begin{array}{l}\text { ASSIA } \\
\text { SSA } \\
\text { SSCI }\end{array}$ & - $\quad$ Self-efficacy linked to human caring and organizational culture. & $\begin{array}{l}\text { Survey. Quantitative methods using survey design to measure IRE-CW } \\
\text { (intention to remain employed in child welfare); HCI-SW (human caring } \\
\text { inventory - social work); SEA-SW (self efficacy assessment - social work); } \\
\text { POCQ-SW (professional organizational culture questionnaire) }\end{array}$ \\
\hline 21 & $\begin{array}{l}\text { Ellett } \\
2007 \\
\text { USA }\end{array}$ & GS & $\begin{array}{l}\text { - Positive relationship between Self-efficacy beliefs and intentions to } \\
\text { remain employed in child welfare. } \\
\text { - These findings replicated across the two states. }\end{array}$ & $\begin{array}{l}\text { Survey. Quantitative research. Survey design (n=941). Measures include SEA- } \\
\text { SW (Self Efficacy Assessment- Social Work); IRE-CW (Intent to Remain } \\
\text { Employed - Child Welfare); Social Desirability Index (SDI). }\end{array}$ \\
\hline 22 & $\begin{array}{l}\text { Ellett } \\
2006\end{array}$ & GS & $\begin{array}{l}\text { Organizational factors contributing to employee turnover } \\
\text { - } \quad \text { extremely large case/workloads resulting in front line workers and }\end{array}$ & $\begin{array}{l}\text { Qualitative methodology. Fifty-eight focus group interviews completed in this } \\
\text { study with a total of } 369 \text { professional staff representing all levels of the agency }\end{array}$ \\
\hline
\end{tabular}




\begin{tabular}{|c|c|c|c|c|}
\hline & USA & & $\begin{array}{l}\text { supervisors working 50-60 hours per week (in some cases more than } \\
70 \text { hours per week) } \\
\text { an atmosphere and organizational culture of tension and fear (e.g., } \\
\text { most employees are hired into unclassified positions without Merit } \\
\text { System protections; criticism from the Media, courts, public, other } \\
\text { professionals, and clients; second guessing case decisions of child } \\
\text { safety; fear for personal safety; fear of dismiSSAl and of criminal and } \\
\text { civil liability for doing their jobs) } \\
\text { salaries are not competitive with other social and human service } \\
\text { agencies, and comparable professions (e.g., teaching, nursing), few } \\
\text { promotional opportunities (i.e. no clear career path within DFCS child } \\
\text { welfare) } \\
\text { employees are not valued by DFCS, policy makers, or the general } \\
\text { public } \\
\text { inadequate client resources (particularly inadequate numbers of foster } \\
\text { and adoptive families for children in DFCS custody) } \\
\text { inadequate selection and hiring processes (too many staff are hired for } \\
\text { child welfare positions without the requisite knowledge, skills, } \\
\text { abilities, and dispositions to be successful with this population) } \\
\text { the court system creates many impediments to child welfare (e.g., great } \\
\text { variety in the quality of working relationships with judges and } \\
\text { attorneys) } \\
\text { communication structure in DFCS is problematic, especially around } \\
\text { policy development and interpretation } \\
\text { too much paperwork (50-75\% of work time) } \\
\text { training provided to new hires was of mixed quality, and mentoring } \\
\text { and professional development opportunities were insufficient } \\
\text { unstable central leadership in DFCS with leadership changes driven by } \\
\text { adverse publicity and politics. } \\
\text { - } \text { Organizational factors contributing to employee retention } \\
\text { - } \text { job benefits including retirement if an employee works long enough to } \\
\text { become vested in the retirement system } \\
\text { flexibility in work hours to attend to personal emergencies, } \\
\text { unexpected events, etc. (colleagues are allowed to work cooperatively } \\
\text { with one another in these situations) } \\
\text { exciting, challenging, unpredictable, constantly changing work } \\
\text { leadership that values employees. } \\
\text { entant and meaningful work } \\
\text { - }\end{array}$ & and all job assignments in child welfare. \\
\hline 23 & $\begin{array}{l}\text { Ellett } \\
2001\end{array}$ & $\begin{array}{l}\text { ASSIA } \\
\text { SSA }\end{array}$ & $\begin{array}{l}\text { - Self-efficacy linked to human caring and organizational culture. This } \\
\text { study addressed personal and organizational factors related to }\end{array}$ & $\begin{array}{l}\text { Survey. Quantitative methodology. The study used large sample survey and } \\
\text { quantitative data analysis methods to examine relationships among elements of }\end{array}$ \\
\hline
\end{tabular}




\begin{tabular}{|c|c|c|c|}
\hline & USA & P Info & employee retention in child welfare. \\
\hline 24 & $\begin{array}{l}\text { Gibbs } \\
2001 \\
\text { Australia }\end{array}$ & GS & $\begin{array}{l}\text { - Supervision - Review of practice. Acknowledgement of the emotional } \\
\text { impact of child protection social work and the significance of } \\
\text { supervision. }\end{array}$ \\
\hline 25 & $\begin{array}{l}\text { Gibbs } \\
2009 \\
\text { Australia }\end{array}$ & $\begin{array}{l}\text { ASSIA } \\
\text { SSA } \\
\text { CINAHL }\end{array}$ & $\begin{array}{l}\text { - The emotional toll of the work is explored. } \\
\text { The paper looks at what needs to change about organizational } \\
\text { structures such as supervision to promote learning within a more } \\
\text { healthy organizational culture. A clear message from senior managers } \\
\text { and politicians to workers that the organization endorses the open } \\
\text { expression of feelings, doubts and uncertainties is pivotal. }\end{array}$ \\
\hline 26 & $\begin{array}{l}\text { Glisson } \\
2006 \\
\text { USA }\end{array}$ & Med & $\begin{array}{l}\text { Organizational intervention strategies can be used to reduce staff } \\
\text { turnover and improve organizational climates in urban and rural child } \\
\text { welfare and juvenile justice systems. }\end{array}$ \\
\hline 27 & $\begin{array}{l}\text { Healy } \\
2009 \\
\text { UK } \\
\text { Australia } \\
\text { Sweden }\end{array}$ & $\begin{array}{l}\text { CIN } \\
\text { SSCI }\end{array}$ & $\begin{array}{l}\text { - Retention disincentives (push factors) and alternative career } \\
\text { opportunities (pull factors) contribute to high turnover among frontline } \\
\text { practitioners. Based on these findings, we propose a strategy for } \\
\text { enhancing workforce retention at the frontline in child protection. The } \\
\text { strategy involves creation of a career pathway that enables, and } \\
\text { encourages, novice child protection workers to become advanced } \\
\text { practitioners. }\end{array}$ \\
\hline 28 & $\begin{array}{l}\text { Healy } \\
2007 \\
\text { Australia }\end{array}$ & GS & $\begin{array}{l}\text { The findings indicated that child welfare workers and employers are } \\
\text { ambivalent about the value of social work and other generic social } \\
\text { science and human services programmes as preparation for tertiary or } \\
\text { statutory child protection practice, which involves investigation, } \\
\text { assessment, and intervention in child abuse and neglect. } \\
\text { It is argued that the social work profession must better balance generic } \\
\text { and specialist aspects to prepare graduates for practice in specialist } \\
\text { fields of high social work involvement, particularly in tertiary child } \\
\text { protection. }\end{array}$ \\
\hline 29 & $\begin{array}{l}\text { Horwitz } \\
2006 \\
\text { USA }\end{array}$ & $\begin{array}{l}\text { ASSIA } \\
\text { SSA } \\
\text { SSCI } \\
\text { P Info }\end{array}$ & $\begin{array}{l}\text { Vicarious events were more highly associated with trauma effects }(\mathrm{r}= \\
0.54, \mathrm{p}<0.000) \text { than were direct events }(\mathrm{r}=0.28, \mathrm{p}<0.000) \text {, and } \\
\text { neither job support nor job satisfaction moderated the relationship. } \\
\text { Workplace trauma events accounted for substantial variability in }\end{array}$ \\
\hline
\end{tabular}

professional organizational culture, human caring, self-efficacy, and professional level employees' intentions to remain employed in child welfare in two states (Arkansas and Louisiana). Measures of intent to remain (employed) in child welfare settings, human caring, self-efficacy beliefs, and professional organizational culture were developed to explore linkages among the study variables.

Qualitative research. Comprehensive and focused interviews were conducted during August and September 1998 with 22 child protection workers from two rural areas in the State of Victoria, Australia.

Qualitative methodology. In depth focused interviews over four year period (1998-2000) with new recruits (stayed for four months on average) and stayers (more than 18 months). Supervisors also interviewed at a later stage of the study (2000).

Experimental tests. Using a pre-post, randomized blocks, true experimental design, 10 urban and 16 rural case management teams were randomly assigned to either the ARC (Availability, Responsiveness, and Continuity) organizational intervention condition or to a control condition. The culture and climate of each case management team were assessed at baseline and again after the one-year organizational intervention was completed. In addition, caseworker turnover was assessed by identifying caseworkers on the sampled teams who quit their jobs during the year.

Qualitative. International comparative study, Australia, UK and Sweden using qualitative interviews with child welfare managers, policy analysts and researchers $(n=57)$.

Mixed Methods. A survey of 208 child welfare workers and interviews with 28 senior personnel in child and family welfare agencies to analyse perceptions of the educational preparation of social workers and other human science graduates for this field of practice.

Survey. Quantitative methodology. This paper is an analysis of 54 survey items designed to identify 1) negative workplace events workers have been exposed to, 2) negative workplace effects workers experience and 3) any association between these events and effects. The items were derived from an analysis of child 
welfare workers' reports in discussions at training events that focused on issues of workplace trauma.

Results suggest that supervisor support and availability of resources have a direct impact on workload management. Additionally, supervisor support is significantly associated with worker ability and availability of resources. While worker ability does not directly affect workload management, it is significantly related to availability of resources. Results of this study can be useful to public child welfare agencies by identifying variables associated with increased manageability of employee workloads.

\begin{tabular}{|l|l|l|l|}
\hline 31 & Kyonne & ASSIA & Findings indicate that the workers' positive perception of teamwork \\
& 2009 & SSA & decreases their stated intentions to leave whereas the workers' burnout \\
& USA & P Info & increases their stated intentions to leave.
\end{tabular}

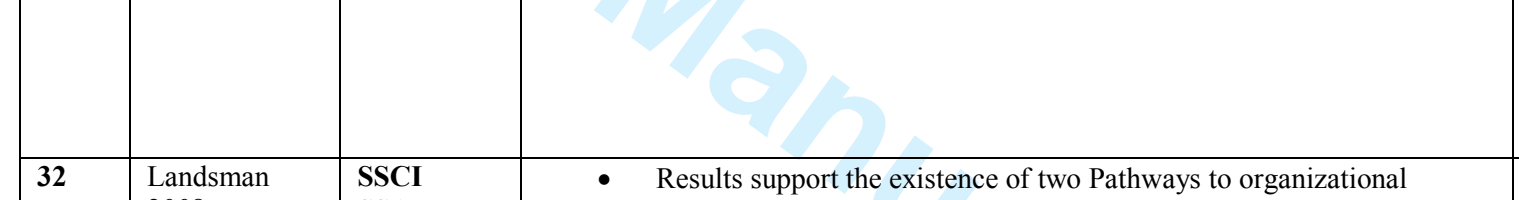

\begin{tabular}{|l|l|l}
32 & SSCI & commitment. Work-related variables to which employees attribute \\
2008 & SSA & cosh
\end{tabular} greater employer responsibility affect employees' commitment through the social exchange Mediator of perceived organizational support, while aspects of work to which employees attribute less employer responsibility affect commitment through job satisfaction.

- Supervisor support is unique in affecting commitment through both pathways.

\begin{tabular}{|l|l|l|l|l|}
\hline $\mathbf{3 3}$ & $\begin{array}{l}\text { Landsman } \\
2001 \\
\text { USA }\end{array}$ & SSCI & $\begin{array}{l}\text { - } \\
\text { The results show that job satisfaction and organizational and } \\
\text { occupational attachment are distinct but related constructs that are } \\
\text { influenced by structural features of the workplace, job stressors, and } \\
\text { professional identification. }\end{array}$ \\
\hline $\mathbf{3 4}$ & $\begin{array}{l}\text { McGowan } \\
2009 \\
\text { USA }\end{array}$ & $\begin{array}{l}\text { ASSIA } \\
\text { SSA } \\
\text { SSCI }\end{array}$ & $\begin{array}{l}\text { The organizational and supervisory variables identified as significant } \\
\text { in the logistic regression, as in earlier research, were not significant } \\
\text { when the data were subjected to structural equation modelling. } \\
\text { Instead, findings suggest that career satisfaction and satisfaction with } \\
\text { paperwork are the key determinants of workers' intention to stay. }\end{array}$ \\
\hline $\mathbf{3 5}$ & $\begin{array}{l}\text { Nelson- } \\
\text { Gardell } \\
2003\end{array}$ & $\begin{array}{l}\text { ASSIA } \\
\text { USA }\end{array}$ & $\begin{array}{l}\text { Personal history of primary trauma, childhood abuse or neglect, \& the } \\
\text { heightened risk for secondary traumatic stress in child welfare } \\
\text { workers. }\end{array}$ \\
\hline $\mathbf{3 6}$ & $\begin{array}{l}\text { Nissley } \\
\text { 2005 } \\
\text { USA }\end{array}$ & CIN & $\begin{array}{l}\text { Workers with higher levels of stress were more likely to think about } \\
\text { leaving, while those receiving greater social support were less likely. } \\
\text { Social support did not buffer the effects of organizational stress, but } \\
\text { had some effect in buffering the effects of work-family conflict. }\end{array}$ \\
\hline
\end{tabular}

Longitudinal. Quantitative methodology using longitudinal design. The initial survey was administered to CPS employees $(n=350)$ at the end of a six-week training academy. Subsequent surveys were administered at six months, eighteen months, and three years. Surveys were developed to reflect the training workers received and how they utilized it. The retention items were developed based on a review of the empirical literature on retention and turnover. The data for this study were extricated from the one-year survey, those hired between January and December of 2002.

Survey. Quantitative methodology. This study, using an analysis of secondary data, develops a construct of "teamwork" to study its relationship to turnover. The study specifically explores "teamwork" compared with individual workrelated factors - burnout and job satisfaction; one work environment factor organizational climate and one personal factor/educational background. Logistical regression analysis was conducted on an anonymous random sample of 319 public child welfare caseworker's responses to an organization wide survey conducted in one U.S. Midwestern state in 2005.

Survey. Quantitative method. Survey questionnaire measuring demographic information and areas related to organizational climate. $(n=456)$

Survey. Quantitative survey of 1,133 public child welfare workers.

Survey. Quantitative methodology. Survey design questionnaire $(n=447)$ to determine which of the organizational, personal, and supervisory variables identified in prior research on this topic are most associated with intent to leave among employees in urban and rural child welfare settings.

Survey. Quantitative methods. Based on a sample of 166 child welfare workers $\&$ using standardized measures, the study findings document the link between a personal history of primary trauma, childhood abuse or neglect, \& the heightened risk for secondary traumatic stress in child welfare workers. related to demographic information as well as other areas related to social support, organizational stress, intention to leave and work/family conflict.
Survey. Quantitative survey, cross sectional design. $(\mathrm{n}=418)$ Measurements 


\begin{tabular}{|c|c|c|c|c|}
\hline 37 & $\begin{array}{l}\text { Nordick } \\
2002 \\
\text { USA }\end{array}$ & GS & $\begin{array}{l}\text { - Career child protection workers love their labour and provide a labour } \\
\text { of love. Certain workers not only avoid burnout and survive in their } \\
\text { jobs, they thrive. }\end{array}$ & $\begin{array}{l}\text { Qualitative methods using in-depth interviews. The author, using grounded } \\
\text { theory methods, reviews the literature and describes the interviews of six } \\
\text { "healthy" child protection workers who defy the stress of their work. The } \\
\text { research also describes the interviews of two workers who had succumbed to } \\
\text { stress. }\end{array}$ \\
\hline 38 & $\begin{array}{l}\text { O Donnell } \\
2009 \\
\text { USA }\end{array}$ & $\begin{array}{l}\text { ASSIA } \\
\text { SSA }\end{array}$ & $\begin{array}{l}\text { The most consistent predictor of whether MSWs stayed past their } \\
\text { stipend commitment was organizational commitment. Other significant } \\
\text { predictors varied by year and included burnout, working conditions, } \\
\text { supervisor support, job satisfaction, role conflict and autonomy. } \\
\text { Qualitative findings about the reasons why these graduates decided to } \\
\text { remain or leave the agency are also presented. }\end{array}$ & $\begin{array}{l}\text { Mixed Methods Longitudinal. Using a discriminant function analysis, factors } \\
\text { taken at the end of the first and second year of employment were used to predict } \\
\text { whether these graduates left prior to or at the end of their commitment or stayed } \\
\text { past their commitment. Qualitative findings also gave detail to why workers } \\
\text { stayed or left }(\mathrm{n}=201) \text {. }\end{array}$ \\
\hline 39 & $\begin{array}{l}\text { Perrone } \\
2007 \\
\text { USA }\end{array}$ & P Info & $\begin{array}{l}\text { - The study examined the relationship between burnout, job satisfaction, } \\
\text { and perceived supervisor support and work environment. } \\
\text { Results of this study are contrary to the theoretical model used in this } \\
\text { study. Based on the previously reported relationships between } \\
\text { increased supervisory support as measured by the WES instrument and } \\
\text { decreased burnout as measured by the MBI instrument, this study } \\
\text { revealed no such significant relationship. } \\
\text { Based on the previously reported relationships between increased } \\
\text { positive work environment as measured by the WES instrument and } \\
\text { decreased burnout as measured by the MBI instrument, this study } \\
\text { revealed no such significant relationship. } \\
\text { Finally, based on the previously reported relationships between } \\
\text { increased burnout as measured by the MBI instrument and decreased } \\
\text { job satisfaction as measured by the MSQ instrument, this study } \\
\text { revealed no such significant relationship. As a result of the findings, } \\
\text { none of the alternative hypotheses can be accepted in this research } \\
\text { study. }\end{array}$ & $\begin{array}{l}\text { Survey. This study utilized a quantitative, non-experimental survey research } \\
\text { design to determine the relationships between variables work environment, } \\
\text { supervisor support, job satisfaction, and level of burnout experienced by a } \\
\text { representative sample of Child Welfare Family Case Managers, }(n=99) \text {. }\end{array}$ \\
\hline 40 & $\begin{array}{l}\text { Regehr } \\
2004 \\
\text { Canada }\end{array}$ & GS & $\begin{array}{l}\text { Individuals with a greater sense of control over their lives and a better } \\
\text { ability to engage in meaningful relationships with others reported } \\
\text { lower levels of distress. In addition, those who had less recent and less } \\
\text { frequent exposures reported lower levels of distress. } \\
\text { The strongest predictor was the organizational environment one aspect } \\
\text { of which was ongoing, chronic stressors. It thus appears that critical } \\
\text { events in child welfare practice are encountered by individuals, whose } \\
\text { resources may already be taxed through coping on an ongoing basis } \\
\text { with high levels of challenge and stress, thereby increasing the } \\
\text { intensity of trauma reactions. }\end{array}$ & $\begin{array}{l}\text { Survey. Quantitative survey design. Questionnaires were distributed to all staff } \\
\text { following meetings describing the nature of the study. A total of } 175 \\
\text { questionnaires were returned from front line, clerical and management staff, } 156 \\
\text { of these was fully completed and useable in this analysis. }\end{array}$ \\
\hline 41 & $\begin{array}{l}\text { Renner } \\
2009 \\
\text { USA }\end{array}$ & Med & $\begin{array}{l}\text { Analyses support hypotheses that retention of workers improved in the } \\
\text { year following the implementation of the supervisory plan, and } \\
\text { measures of supervisor effectiveness, team effectiveness, and job } \\
\text { satisfaction also increased. }\end{array}$ & $\begin{array}{l}\text { Longitudinal Quantitative survey design using self-response survey } \\
\text { questionnaire that consists of five dimensions that assess the total workplace } \\
\text { environment and profile areas of organizational strength and concern. Average } \\
\text { participation for workers was } 868 \text { (workers) and } 153 \text { (supervisors). }\end{array}$ \\
\hline
\end{tabular}


This study uses employee responses from six time points (2003 to 2008) to capture trends across the state and focus on responses from public workers and supervisors. ( $\mathrm{n}=1467$ average)

Survey. Quantitative Methodology. Transpersonal theory served as the

framework for the study. The design was a cross-sectional, correlational study. The multivariate hypothesis was as follows: Controlling for age, gender, length of employment, and job assignment, child welfare social workers with lower levels of coping and lower levels of spirituality will have higher levels of burnout. The hypothesis was tested using multiple regression analysis. The sample of child welfare social workers was obtained using convenience sampling. $(\mathrm{n}=106)$

\begin{tabular}{|l|l|l|ll}
\hline 43 & $\begin{array}{l}\text { Rosenthal } \\
\text { 2006 }\end{array}$ & SSCI & & $\begin{array}{l}\text { Participation in a IV-E-funded social work educational program } \\
\text { predicted better retention. In particular, risk of termination decreased } \\
\text { bSA } 52 \% \text { during the mandated contractual employment period in which }\end{array}$ \\
\end{tabular} the educational stipend was "worked off".

- Other predictors of longer retention included prior non-child welfare employment at the public agency and working in the state office setting. Temporary job classification predicted higher risk of termination.

- With temporary classifications excluded, female gender predicted better retention.

- Neither county of employment nor supervisor explained significant variance in retention.

- Involvement with the IV-E funded social work program was not associated significantly with supervisory ratings.

- Regression analyses revealed an association between an ethnic group's representation in the population of child welfare workers and supervisory evaluation; the greater that representation, the higher the overall evaluation for the group.

\begin{tabular}{|c|c|c|c|}
\hline & & & 110 \\
\hline 44 & $\begin{array}{l}\text { Scannapieco } \\
2007\end{array}$ & Med & $\begin{array}{l}\text { It was found supervisors and co-workers play a crucial role in the } \\
\text { retention of workers. }\end{array}$ \\
\hline
\end{tabular}

\begin{tabular}{l|l|l}
\hline 45 & Schwartz & SSA \\
& 2008 & ASSIA
\end{tabular}

USA

- The findings demonstrate that burnout and engagement Mediate the effects that demands and resources have on intent to leave.

- Supervisor support exerted both direct and indirect effects on intent to leave.

- The results support the inclusion of work engagement in burnout research, demonstrate the psychometric soundness of two new instruments to measure engagement and burnout, and support the applicability of the Job Demands Resources Model to a sample of social service workers employed in public child welfare.

- The findings indicate that job demands and resources play an
Methods Longitudinal. Review of secondary records. Using administrative records, this paper tracks for up to four years using Cox survival methods the retention of 839 public child welfare workers who began child welfare work in 1999. It also examines, using ordinal logistic regression, supervisory performance evaluations of 382 of these workers.

\section{Longitudinal. Quantitative survey design. A sample of 1100 employees}

participated in this study at two periods. First at graduation and again after being employed in the field for at least three months. The study included employees and supervisors following first year of a training programme. It captures the experiences of those in post and those who have left.

Survey. Quantitative survey data were collected from 243 public child welfare workers. Oldenburg Burnout Inventory and Job engagement measure used. 


\begin{tabular}{|c|c|c|c|c|}
\hline & & & important role in worker intent to leave. & \\
\hline 46 & $\begin{array}{l}\text { Shepel } \\
2009 \\
\text { Canada }\end{array}$ & $\begin{array}{l}\text { ASSIA } \\
\text { SSA }\end{array}$ & $\begin{array}{l}\text { - Impact of vicarious traumatisation and secondary traumatic stress on } \\
\text { Aboriginal child welfare social workers who may also have been } \\
\text { residential school survivors, children of residential school survivors, or } \\
\text { experienced childhood trauma. } \\
\text { Research hypotheses sought to test whether inclusion in any of these } \\
\text { categories would increase the incidence of vicarious traumatisation and } \\
\text { secondary traumatic stress amongst Aboriginal child welfare social } \\
\text { workers who were then subsequently exposed to their clients' trauma } \\
\text { stories. }\end{array}$ & $\begin{array}{l}\text { Survey. Quantitative descriptive study sought to explore the impact of vicarious } \\
\text { traumatisation and secondary traumatic stress on Aboriginal child welfare social } \\
\text { workers who may also have been residential school survivors, children of } \\
\text { residential school survivors, or experienced childhood trauma. Anonymous } \\
\text { cross-sectional survey regarding the impact of work on their professional and } \\
\text { personal lives. Insufficient sample size prevented testing of the research } \\
\text { hypotheses but the study sample clinical data were notable. }\end{array}$ \\
\hline 48 & $\begin{array}{l}\text { Song KI Bum } \\
2006 \\
\text { USA }\end{array}$ & $\begin{array}{l}\text { ASSIA } \\
\text { SSA }\end{array}$ & $\begin{array}{l}\text { - Results support the proposed Mediating role of fear of future } \\
\text { victimization between past victimization and the outcome variables- } \\
\text { burnout, affective commitment, and turnover intention. } \\
\text { The results indicate that male social workers are less likely to be } \\
\text { fearful of client violence than their counterparts. Implications for how } \\
\text { to deal with fear of victimization and the prevention of client violence } \\
\text { in both the administration and the policy level are discussed. }\end{array}$ & $\begin{array}{l}\text { Survey. Quantitative methodology. The primary aims of this study were two } \\
\text { fold; to examine the prevalence of client violence toward child \& family welfare } \\
\text { social workers and to explore the proposed structural relationships among five } \\
\text { latent variables (past victimization from client violence, fear of future } \\
\text { victimization from client violence, burnout, organizational commitment, and } \\
\text { turnover intention). A multiple group analysis was conducted to test the moderate } \\
\text { effect of gender on the path from past victimization to fear. A survey instrument } \\
\text { was mailed to a national sample of } 1,000 \text { child \& family welfare social workers } \\
\text { randomly selected from the } 2004 \text { membership directory of National Association } \\
\text { Social Workers. }\end{array}$ \\
\hline 49 & $\begin{array}{l}\text { Stalker } \\
2007 \\
\text { USA }\end{array}$ & $\begin{array}{l}\text { SSCI } \\
\text { ASSIA } \\
\text { SSA } \\
\text { P Info } \\
\text { SCO }\end{array}$ & $\begin{array}{l}\text { Considerable evidence supports the positive influence of variables } \\
\text { organizational managers can control, including job autonomy, } \\
\text { supportive supervisors, workload, promotional opportunities and } \\
\text { perception of personal safety. }\end{array}$ & $\begin{array}{l}\text { Literature Review. Six quantitative studies that assessed both JS and EE in } \\
\text { samples of child welfare employees were located. }\end{array}$ \\
\hline 50 & $\begin{array}{l}\text { Stevens and } \\
\text { Higgins } \\
2002 \\
\text { Australia }\end{array}$ & $\begin{array}{l}\text { P Info } \\
\text { ASSIA } \\
\text { SSA }\end{array}$ & $\begin{array}{l}\text { - Workers reported high levels of emotional exhaustion and } \\
\text { depersonalization, and a low to moderate sense of personal } \\
\text { accomplishment. } \\
\text { - Family background characteristics predicted the occurrence of } \\
\text { maltreatment and current adjustment, and a personal history of } \\
\text { maltreatment predicted current trauma symptoms, but not burnout. } \\
\text { - Workers most frequently used problem-focused coping strategies and } \\
\text { sought social support; however, coping strategies were not associated } \\
\text { with the level of either trauma symptoms or burnout. } \\
\text { Despite employing positive coping strategies, their efficacy may be } \\
\text { affected by other interpersonal, intra-individual and job resource } \\
\text { issues. }\end{array}$ & $\begin{array}{l}\text { Survey. Quantitative survey design. Self-report questionnaire assessing } \\
\text { childhood maltreatment, family background characteristics, current adjustment, } \\
\text { coping strategies, and burnout }(\mathrm{n}=44) \text {. }\end{array}$ \\
\hline
\end{tabular}




\begin{tabular}{|c|c|c|c|}
\hline 51 & $\begin{array}{l}\text { Strand } \\
2009 \\
\text { USA }\end{array}$ & SSCI & $\begin{array}{l}\text { - Results indicate that length of employment, being a supervisor, and } \\
\text { experiencing difficulties with working conditions, supervision, and the } \\
\text { lack of external client resources predict the highest levels of job } \\
\text { dissatisfaction. } \\
\text { Implications for public child welfare organizations are discussed, } \\
\text { including strategies for attending organizational factors that negatively } \\
\text { affect employees' perceptions of organizational support. }\end{array}$ \\
\hline 52 & $\begin{array}{l}\text { Strolin- } \\
\text { Goltzman } \\
\text { Auerbach } \\
\text { McGowan } \\
\text { McCarthy } \\
2009 \\
\text { USA }\end{array}$ & $\begin{array}{l}\text { SSA } \\
\text { SSCI } \\
\text { Med }\end{array}$ & $\begin{array}{l}\text { Findings suggest that there are unique influences on intention to leave } \\
\text { among the three localities. (Seven factors influencing the decision to } \\
\text { leave: life/work fit; efficacy and job satisfaction; salary and benefits; } \\
\text { supervisory support; tenure; possession of a social work degree; race; } \\
\text { and lack of job options). }\end{array}$ \\
\hline 53 & $\begin{array}{l}\text { Strolin } \\
\text { Goltzman } \\
\text { Auerback } \\
\text { Caringi } \\
\text { Claiborne } \\
\text { Lawson } \\
\text { McCarthy } \\
\text { McGowan } \\
\text { Sherman } \\
\text { Shim } \\
\text { 2009 } \\
\text { USA }\end{array}$ & CIN & $\begin{array}{l}\text { This study adds to the knowledge base by (1) describing an } \\
\text { organizational intervention aimed at addressing the organizational } \\
\text { causes of turnover; (2) analyzing quantitative changes in actual } \\
\text { turnover rates as well as organizational factors; and (3) analyzing } \\
\text { supplemental qualitative data to provide a deeper understanding of the } \\
\text { organizational changes that occurred through the course of the } \\
\text { intervention. }\end{array}$ \\
\hline 54 & $\begin{array}{l}\text { Strolin } \\
\text { Goltzman } \\
2008 \\
\text { USA }\end{array}$ & CIN & $\begin{array}{l}\text { This comparison study analyses the commonalties, similarities, and } \\
\text { differences on supervisory and organizational factors between a group } \\
\text { of high turnover systems and a group of low turnover systems. } \\
\text { Significant differences on organizational factors, but not on } \\
\text { supervisory factors, emerged from the statistical analysis. Additionally, } \\
\text { this study found that low turnover is not necessarily predictive of a } \\
\text { healthy organizational environment. Implications for turnover } \\
\text { reduction and prevention are provided in conclusion. }\end{array}$ \\
\hline 55 & $\begin{array}{l}\text { Szu-Yu Chen } \\
2009 \\
\text { USA }\end{array}$ & GS & $\begin{array}{l}\text { Findings revealed that job satisfaction had substantial impacts on } \\
\text { improving worker's desire to stay under most of the circumstances, } \\
\text { except for the circumstance when workers concurrently perceiving low } \\
\text { work related self-efficacy and low supervisor's support. } \\
\text { Finding also revealed that supervisor's support was particularly } \\
\text { important to retain workers of low self-efficacy. }\end{array}$ \\
\hline
\end{tabular}

Survey. Quantitative survey questionnaires. Survey responses from 927 respondents, five research questions were addressed: 1) How does job satisfaction compare to staff in other human service organizations nationally? 2. Are differences in staff characteristics related to job satisfaction? 3. Are there particular areas of job difficulty that predict job satisfaction? 4. Are there differences by job category in job satisfaction? 5 . What staff or job-related factors predict job satisfaction?

Survey. Quantitative survey methods used. Eight hundred and twenty workers and supervisors from twenty-five child welfare agencies participated in a survey addressing organizational, individual, and supervisory factors related to workforce turnover.

Quasi-experimental study, using mixed methodology, investigating the effects of an intervention (Design Team - DT) designed to address organizational causes of turnover in public child welfare. Organizational and supervisory factors were measured through workforce retention surveys administered to workers in the 12 intervention and comparison counties prior to and following the intervention. Approximately $70 \%$ of workers $\left(N_{-}\right.$526) completed the surveys at pre- and posttest. However, this analysis is a county agency level analysis $\left(\begin{array}{ll}N & 12\end{array}\right)$, not an individual analysis. In other words, the same people may not have completed the survey at pre- and post-test, and therefore, the data represent a composite view of the entire agency as a snapshot prior to the intervention and again postintervention. Qualitative analysis and cross case analysis of naturally occurring data generated during the DT intervention was examined during this study. Survey. Quantitative methodology using child welfare workforce retention survey was the instrument used for this study. The survey included a total of 115 items of which 64 were related to organizational issues and 24 were related to supervisory issues. The remaining items consisted of demographic variables such as age, race, or length of time on the job. The review yielded eight possible causes of turnover and retention and resulted in the inclusion of questions addressing each of these substantive areas: clarity of practice, work-life fit, job satisfaction, job supports and commitment, paperwork, salary and benefits, supervisor support and supervisor competency. $(\mathrm{N}=667)$.

Longitudinal. Quantitative longitudinal study design. The present study utilized secondary data from an ongoing longitudinal study conducted by the Texas Protective Services Training Institute since November 2001. This evaluation involved distributing survey questionnaires at different time points to collect responses of Child Protective Service (CPS) workers after their participation in the Texas Child Protective Services Basic Skills Development (BSD) job training 
program. The survey questionnaires were developed by a team of researchers with inputs from CPS, Basic Skills Development (BSD) trainers, and Texas Department of Family and Protective Services administrators. The present study derived research variables from this data set to study the responses of CPS workers who completed the BSD training between November 2001 and March $2008(\mathrm{n}=455)$.

Survey. Quantitative methodology. Questionnaires were distributed to 309 social workers in child welfare in the County of Stockholm (drop-out rate: 3 per cent). The study comprised a total of forty-two workgroups. All the social workers handling referrals and investigating the situation of children and youth in these areas were included.

Survey. This study compared survey data collected among social workers in child welfare $(\mathrm{N}=309)$ with a sample $(\mathrm{n}=4,271)$ taken from a more extensive survey $(\mathrm{N} 1 / 422,532)$ by researchers at the Karolina Institute of municipal and county council personnel in Sweden (the KI/AFA study). Use of a common instrument - the Nordic Questionnaire for Psychological and Social Factors at Work or 'QPS Nordic' (Dallner et al., 2000) — made the comparison possible.

Survey. Quantitative Methodology. The sample consists of practitioners $(\mathrm{N}=$ 945) working in youth centers or in local community service centers. Data are collected through self-administered questionnaires prior to and after the program. Objective: To test the effectiveness of an in-training program for practitioners in public child welfare organizations

Experimental Design. A design study based on pre-test and post-test measurements was used. Two periods of measurement were scheduled: (a) immediately before the training began (PRE), and (b) immediately after the training ended (POST).This article examines the determinants of work atisfaction among practitioners in this field. Participants completed a 41-item multiple-choice knowledge test developed jointly by the research team 


\begin{tabular}{|c|c|c|c|c|}
\hline & & & & $\begin{array}{l}\text { and the NTP unit. It represented a consensus about foundation-level knowledge } \\
\text { that is considered essential to effective child welfare practice. The results are } \\
\text { based on a study conducted with } 450 \text { practitioners. }\end{array}$ \\
\hline 60 & $\begin{array}{l}\text { Van Hook } \\
2009 \\
\text { USA }\end{array}$ & $\begin{array}{l}\text { SSA } \\
\text { ASSIA }\end{array}$ & $\begin{array}{l}\text { Compassion satisfaction was positively associated with lower levels of } \\
\text { burnout and fatigue. Levels of burnout and compassion fatigue were } \\
\text { similar to other helping professions but higher for younger workers } \\
\text { and both direct line staff and supervisors working with the most } \\
\text { vulnerable and troubled situations. Respondents indicated the need for } \\
\text { realistic caseloads and administrative support. }\end{array}$ & $\begin{array}{l}\text { Survey. Quantitative methodology. Survey using The Professional Quality of } \\
\text { Life Survey and questions regarding ways respondents dealt with stress and their } \\
\text { recommendations for organizations. }(\mathrm{n}=182 \text { ) }\end{array}$ \\
\hline 61 & $\begin{array}{l}\text { Vu,Paul } \\
\text { Hoang } \\
2007 \\
\text { USA }\end{array}$ & $\begin{array}{l}\text { ASSIA } \\
\text { SSA }\end{array}$ & $\begin{array}{l}\text { Results found that child welfare workers in Los Angeles have high } \\
\text { levels of job effectiveness }(74.1 \%) \text {, high levels of potential } \\
\text { professional burnout }(75.9 \%) \text {, and moderate levels of vicarious trauma } \\
(35.2 \%) \text { and those workers who self-report using more positive coping } \\
\text { strategies were experiencing lower levels of the trauma. }\end{array}$ & $\begin{array}{l}\text { Survey. Quantitative methodology. Fifty-six Children's Social Workers at the } \\
\text { Lakewood Office participated in the study by completing a survey that assesses } \\
\text { their level of vicarious trauma using a standardized instrument, ProQOL R-IV, as } \\
\text { well as their self-reported coping strategies. }\end{array}$ \\
\hline 62 & $\begin{array}{l}\text { Weaver } \\
2007 \\
\text { USA }\end{array}$ & $\begin{array}{l}\text { ASSIA } \\
\text { SSA } \\
\text { SSCI } \\
\text { CIN }\end{array}$ & $\begin{array}{l}\text { - Attitudes of workers in response-to-job conditions are more likely to } \\
\text { predict intention to leave than actually leaving. } \\
\text { Time to receiving a full caseload, which is under the control of } \\
\text { administrators, is an important predictor of leaving the job. Other } \\
\text { lessons for administration are discussed. }\end{array}$ & $\begin{array}{l}\text { Survey - Longitudinal Design. Quantitative Survey Design. Longitudinal study } \\
\text { developing predictors of turnover among newly hired public child welfare } \\
\text { workers. Comparisons are made between predictors of intention to leave and } \\
\text { predictors of actually leaving the job as alternative outcomes. An original } \\
\text { quantitative survey instrument was constructed. Standardized scales were drawn } \\
\text { from the existing literature. The instrument was pre-tested on a group of child } \\
\text { welfare workers that were not part of the study. A slightly different version of the } \\
\text { questionnaire was used for the workers who had already left the job. Potential } \\
\text { subjects for this longitudinal study were the } 1700 \text { new public child welfare } \\
\text { workers hired in California's } 58 \text { counties between April } 2000 \text { and April } 2001 \text {. } \\
\text { California's public child welfare system is county-based, so this approach } \\
\text { allowed for variation on job and agency variables. Study results are based on } 141 \\
\text { leavers and } 382 \text { "still in post". }\end{array}$ \\
\hline 63 & $\begin{array}{l}\text { Westbrook } \\
2006 \\
\text { USA }\end{array}$ & $\begin{array}{l}\text { SSCI } \\
\text { CIN }\end{array}$ & $\begin{array}{l}\text { - This study expands understanding of personal and organizational } \\
\text { factors related to retention among public child welfare workers and } \\
\text { supervisors from the personal experiences of highly competent, long- } \\
\text { term employees, following the original terminology used by Ellett and } \\
\text { Ellett (1997), we termed the "committed survivors". }\end{array}$ & $\begin{array}{l}\text { Qualitative methodology. A series of focus group interviews was completed } \\
\text { with } 21 \text { child welfare employees in urban, suburban, and rural } \\
\text { settings. The results of the study are described in six sections: (a) Engagement } \\
\text { and Involvement of Participants; (b) Reminiscence Organizational; (c) } \\
\text { Reminiscence: Societal; (d) Personal Characteristics; (e) Core Themes; and (f) } \\
\text { Group Differences. }\end{array}$ \\
\hline 64 & $\begin{array}{l}\text { Weuste } \\
2006 \\
\text { USA }\end{array}$ & $\begin{array}{l}\text { ASSIA } \\
\text { SSA }\end{array}$ & $\begin{array}{l}\text { The provision of a critical incident debriefing, in a supportive and } \\
\text { neutral interpersonal context, contributed to their reduced sense of } \\
\text { isolation and gave them an opportunity to process the incident which } \\
\text { they reported contributed to their sense of reduced stress. }\end{array}$ & $\begin{array}{l}\text { Mixed methods design. Thirty child welfare workers in Northern Illinois } \\
\text { participated in a debriefing and a follow-up session. This study used a triadic } \\
\text { research design utilizing both quantitative and qualitative methodologies. } \\
\text { Participants took inventories to measure trauma symptoms and to identify the } \\
\text { type of coping responses before and one month after the debriefing. The } \\
\text { debriefing and follow-up session were also audio taped for the qualitative } \\
\text { narrative analysis of their critical incident experience. }\end{array}$ \\
\hline 65 & $\begin{array}{l}\text { Yankeelov } \\
2009\end{array}$ & SSCI & $\begin{array}{l}\text { The results of this study show that the stayers }(\mathrm{N}=448) \text { and leavers }(\mathrm{N} \\
=275) \text { in this child welfare agency did not differ in their gender, race. }\end{array}$ & $\begin{array}{l}\text { Longitudinal. Quantitative research design. This study utilized a non- } \\
\text { experimental, prospective research design. In Phase } 1 \text {, trainees were requested to }\end{array}$ \\
\hline
\end{tabular}




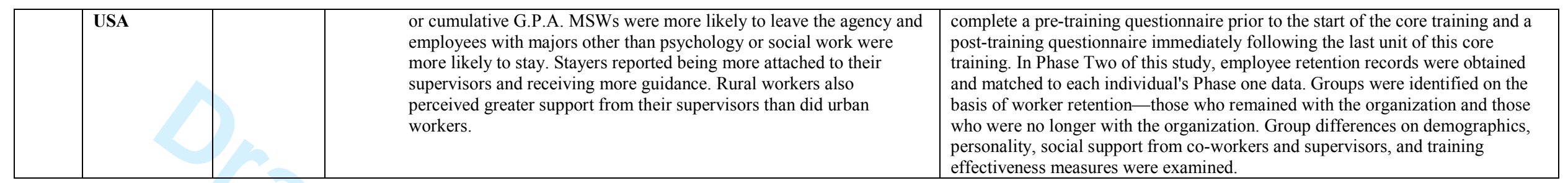

